Eskişehir Osmangazi Üniversitesi İlahiyat Fakültesi Dergisi Journal of Eskişehir Osmangazi University Faculty of Theology ISSN: 2147-8171

التقارض بين حروف الجر عند ابن مالكت

İbn Mâlik'e Göre Harf-i Cerlerde Tekârud/Ödünç Alşsverişi

The Phenomenon of Grammatical "Borrowing "between Prepositions by Ibn Malik

\title{
Turkiy ALALI
}

Y. Lisans Öğrencisi, Eskişehir Osmangazi Üniversitesi, Sosyal Bilimler Enstitüsü, Temel İslam Bilimleri Anabilim Dalı Grad. Student, Eskişehir Osmangazi University, Institute of Social Sciences, Depart. of Basic Islamic Sciences, Eskisehir, Turkey. try198571@gmail.com

(iD) 0000-0002-8287-5251

\section{Prof. Dr. Dursun HAZER}

Eskişehir Osmangazi Üniversitesi, İlahiyat Fakültesi Arap Dili ve Belagati Anabilim Dalı Eskişehir Osmangazi University, Faculty of Theology Depart. of Arabic Language and Rhetoric, Eskişehir / Turkey. hazerdursun@yahoo.com

(iD) $0000-0003-2370-8610$

\begin{tabular}{lcr}
\multicolumn{2}{c}{ Makale Bilgisi / Article Information } \\
& Makale Türü / Article Type & Araştırma Makalesi / Research Article \\
Geliş Tarihi / Received & Kabul Tarihi / Accepted & Yayın Tarihi / Published \\
28 Aralık / December 2020 & 18 Şubat / February 2021 & 17 March / March 2021
\end{tabular}

Atıf Bilgisi / Cite as:

Alali, Turkiy - Hazer, Dursun. “ibn Mâlik’e Göre Harf-i Cerlerde Tekârud/Ödünç Alışverişi”, Eskişehir Osmangazi Üniversitesi İlahiyat Fakültesi Dergisi 8/1 (Mart 2021), 174-201. http://doi.org/1051702/esoguifd.847568.

İntihal / Plagiarism: Bu makale, en az iki hakem tarafından incelenmiş ve intihal içermediği teyit edilmiştir. / This article has been reviewed by least two referees and scanned via a plagiarism software.

Copyright @ Published by Eskişehir Osmangazi Üniversitesi, İlahiyat Fakültesi /Eskişehir Osmangazi University, Faculty of Theology Bütün hakları saklıdır. / All right reserved. https://dergipark.org.tr/tr/pub/esoguifd

CC BY-NC 4.0 This paper is licensed under a Creative Commons Attribution-NonCommercial License

Etik Beyanı / Ethical Statement: Bu çalışmanın hazırlanma sürecinde bilimsel ve etik ilkelere uyulduğu, yararlanılan tüm çalışmaların kaynakçada belirtildiği ve bu araştırmanın desteklenmesi için herhangi bir dış fon alınmadığı yazar tarafından beyan olunur / It is declared by the author that scientific and ethical principles have been followed while carrying out and writing this study; that all the sources used have been properly cited; that no external funding was received in support of the research. 


\section{التقارض بين حروف الجر عند ابن مالك}

$$
\begin{aligned}
& \text { ملخَّص هـ تتميز اللغة العربية بخصائص عديدة تزيد من قوتها وسعتها ورونقها؛ كالتر ادف، و الاشتقاق، و الاشتر اك، } \\
& \text { و التضاد، و الإعر اب، و غير ها من الخصائص. ومن بين هذه الخصائص التقارض في المعنى بين ألفاظها، فقد يتقارض } \\
& \text { حرفان أو حرف وظرف أو غير ذللك؛ ليؤدي معنى اللفظ الذي اقترض منه. ولعل أبرز هذه الألفاظ حروف الجر، } \\
& \text { و هي كثيرة الاستعمال في كلام العرب؛ لذا أَولى النحاة لها الاهتمام في كتبهم. فسردو ا ألفاظها ما اتُّقِقَ عليه وما اختُّلَْ } \\
& \text { فيه. وز ادو ها اهتمام بذكر معانيها بين مقتصد ومتوسع في ذلك إلَّا أنهم درسو ها من ناحية النيابة -وهو أن يؤدي حرف } \\
& \text { معنى حرف آخر -و أكثروا الكلام في ذلك بين مانع لنيابة، وبين متوسط، ومُجِيزٍ لها. وكلٌ منهم ساق أدلته، وحشد } \\
& \text { شو اهده على ذلك، فتناثرت أقو الهم في بطون كُتب التراث العربي. ومن بين هؤلاء النحاة ابن مالك، الذي نصر رأي } \\
& \text { من قال بالتقارض، وتوسع في ذللك، وجمع لموقفه ما لم يجمعه غيره؛ وربما انفرد بأر اء فيها. ور ائده في ذلك السماع } \\
& \text { من كلام العرب نثره وشعره. وقد أسهم موقفه من الاستدلال بالحديث بزيادة شواهده السماعية فعَلَ بالنيابة بين } \\
& \text { الحروف وجعل لها منزلة سار عليها كثير من النحاة بعده. }
\end{aligned}
$$

$$
\text { الكلمات المفتاحية :اللغة العربية وبلاغتها، التقارض، النيابة، حروف الجر، الظروف، ابن مالك. }
$$

\section{İbn Mâlik'e Göre Harf-i Cerlerde Tekârud/Ödünç Alışverişi}

Öz $\gg$ Arap dili, eşanlamlılık, türetme, sesteşlik, karşıt anlamlılık, irap ve bunların dışındaki başka özellikler gibi gücünü ve kapasitesini artıran birkaç özellikle öne çıkmaktadır. Bu özelliklerden biri de kelimeler arasındaki anlamın ödünç alınıp verilmesidir. İki harf bir harf ile zarf veya edatlar ödünç alınan kelimeye anlam katması için ödünç alınıp verilmektedir. Cümle anlaşılmamaktadır. Bu harflerden harfi cerler önemli yer tutmaktadır. Fiilerin anlamlarının isimlerine aktarılmasında harfi cerlerden bazıları birbirlerinin yerlerine kullanılmaktadır. Bir harf-i cer diğer harfi cerin yerine geçerek onun ifade ettiği anlamı ifade etmektedir. İlk nahivcilerden başlayarak İbn Malik'e gelinceye kadar önemli nahivciler Arap dilindeki bu olguya dikkat çekmişlerdir. Gramercilerin arasında ödünç alma konusunda söz söyleyenlere destek çıkan, bu konuda detaylara inen bununla ilgili olarak başkalarının ortaya koymadı̆̆ı delilleri ileri süren belki de bu konuda görüşleri ile tek olan İbn Malik el-Endelusi'dir. Harfler arasındaki bu ilişkiyi niyâbe/yerine geçme olarak isimlendiren İbn Malik kendinden sonra gelen nahivcilerin kullandıkları bir kural haline dönüştürmüştür.

Anahtar Kelimeler: Arap Dili ve Belagatı, Tekârud/ödünç alıp verme, niyâbe/yerine geçme, harf-i cerler, zarflar, İbn Mâlik.

\section{The Phenomenon of Grammatical "Borrowing "between Prepositions by Ibn Malik}

Abstract The Arabic language has several characteristics that increase its strength and capacity, such as synonymousness, derivation, polysemy, antonymy, syntax and other characteristics. Among these words are prepositions, which are frequently used in The Arabs speech, so the grammarians paid attention to their 
Alali-Hazer, The Phenomenon of Grammatical "Borrowing "between Prepositions by Ibn Malik

books. They have narrated its utterances including what were agreed upon and what were disagreed. Some of them were very keen to study them in details and some were concise However, they studied it in terms of the alternation, which is that a letter is used to give the meaning of another letter. They discussed this term in details and varied from grammarians who deny alternation completely, others said it is possible to be used and others said it should be used and everyone presented his evidences, proofs and examples about this term. Their sayings are documented in many of the Books of Arab Heritage. Ibn Malik al-Andalusi was one of those grammarians who supported those who said that "alternation "should be used and studied it in detail and gathered evidence and proofs to support his opinion more than anyone else. He was pioneered in that hearing of the words of Arabic poetry and prose. His attitude on inference to Hadith has contributed to increasing his audio evidence and consequently, he promoted "alternation" between letters putting it in a distinctive place so other grammarians followed him later.

Keywords: Arabic Language and Rhetoric, Contradiction, Prepositions, Prosecution, Adverbs, Ibn Malik.

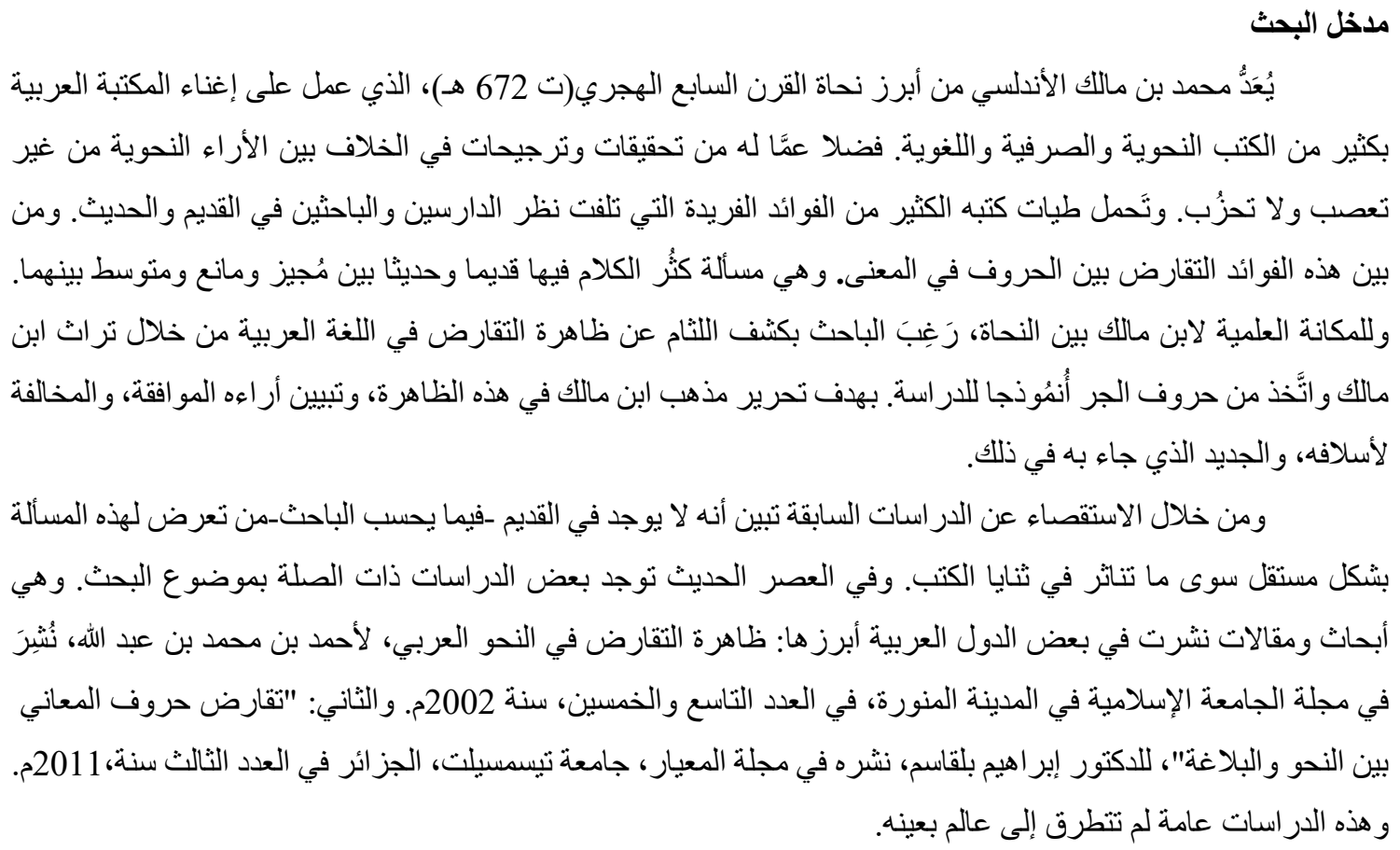


Alali-Hazer, İbn Mâlik'e Göre Harf-i Cerlerde Tekârud/Ödünç Alma

التقارض في اللغة: من القرض و هو ما تعطيه غيرك من مال ليقضاه. 1 ويقال تقارض زيد و عمرو المدح إذا هدح كل

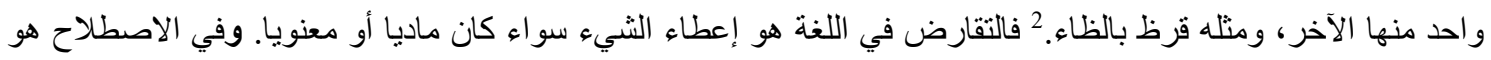

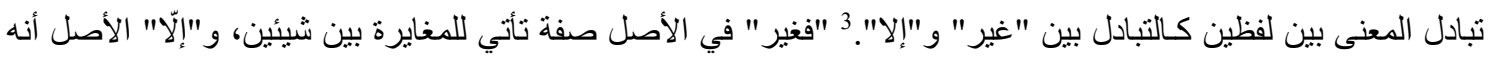

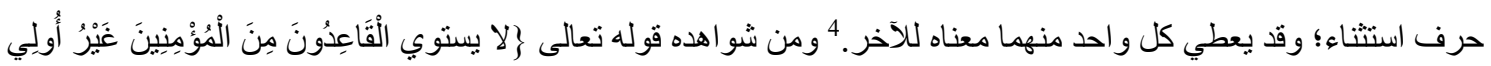

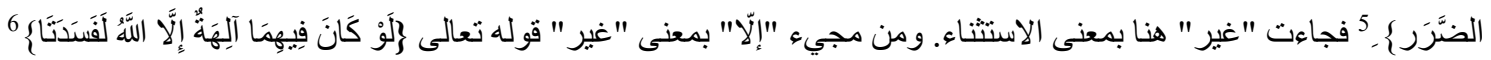

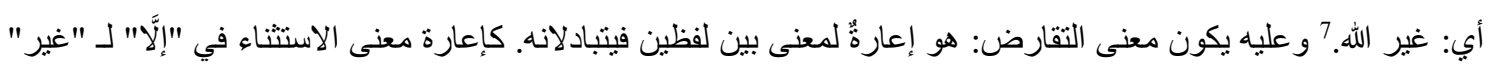

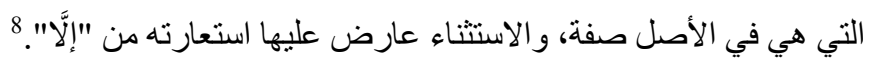
وللفظ التقارض مر ادفات يستخدمُها النحاة في كتبهم كـ "النيابة" و هي قيام لفظ مقام آخر في المعنى. و و "المو افقة" وهو

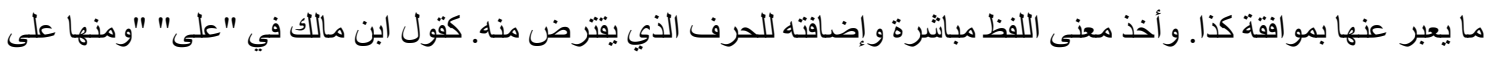

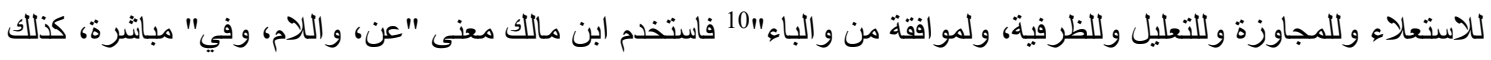

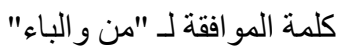

حروف الجر

الحرف في اللغة: من كل شيء طرفه.11 وفي الاصطلاح هو ما جاء لمعنى وليس اسما أو فعلا. 12 والجر لغة:

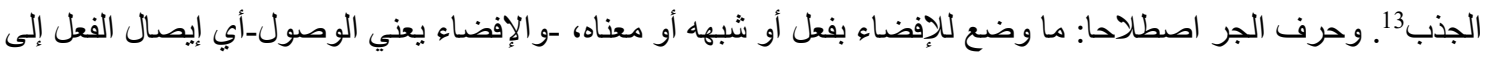

الاسم فيكون الفعل قد تعدى بحرف الجر إلى الاسم.

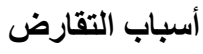

لم يكن التقارض عبثا في كلام العرب بل كان له أسباب أدت إلى استعماله، كبقية خصائص العربية. ولعل أبرز دو اعيه

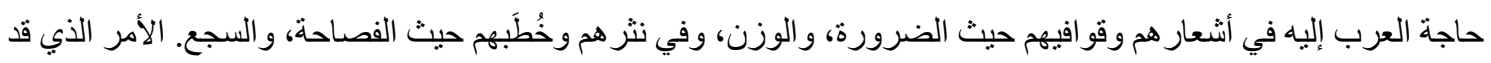
يصرفهم من لفظ إلى آخر لكنهم يُحَمِلون اللفظ الجديد معنى اللفظ المَصروف عنهـ. 15

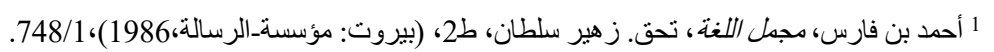

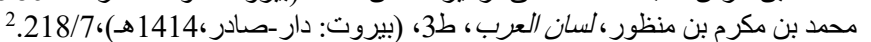

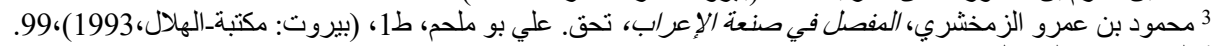

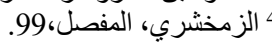

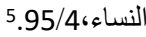

الأنبياء،22/21

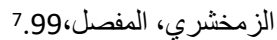

الزمخشري، الدفصل ،

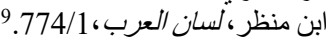

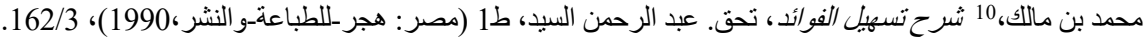

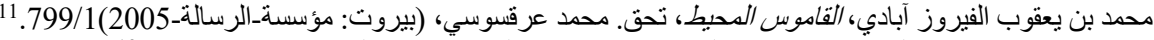

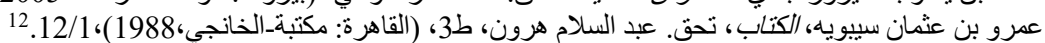

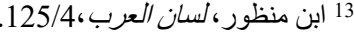

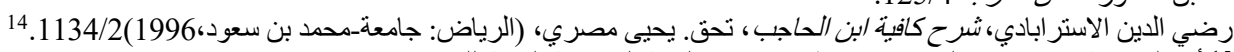
15 أبو الفتح عثمان بن جني، الخصائص، ط4، (مصر : الهيئة المصرية العامة_للكتاب) ،216/1. 


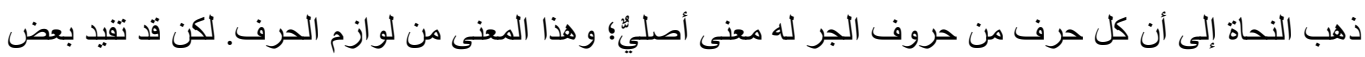
الحروف معانياً ليس أصلا فيها، بل هي لحرف آخر و هذا ما يسمى التقارض بين الحروف. وكأن أحد الحروف أقرض معناه الأصلي لحرفٍ آخر، وقد يسمى باب نيابة الحروف بعضها عن بعض. و هذه المسألة اختلف النحاة فيها على ثلاثة أقو ال:

\section{القول الأول للبصريين}

ذهب البصريون إلى أن حروف الجر لا ينوب بعضها عن بعض. وحُجَتُهم في ذلك أن الحرف يوضع لمعنى، وهذا

المعنى أصل في كل الحروف، ولما كانت حروف الجزم، و النصب لا ينوب بعضها عن بعض؛ قاسوا عليها حروف الجر.

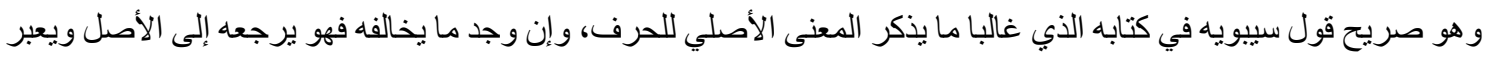

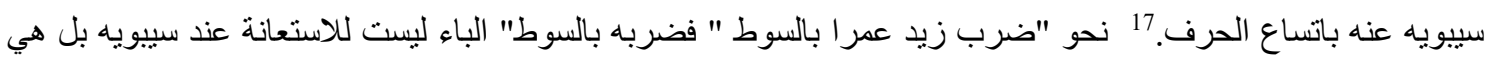
على تقدير ألصق السوط على ظهره، وكذلك "مررت به" على تقدير ألصقت مروي بمكانٍ قريب من مكانه؛ و هو قصد سيبويه

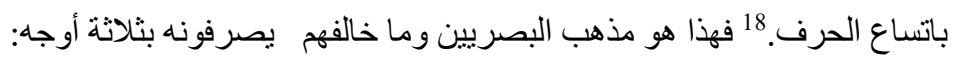
الوجه الأول: تأويل المعنى المخالف بالظاهر تأو يلا يقبله اللفظ. نحو عنده ليست بمعنى "على" بل هي على تشبه المصلوب في تمكنه من الجذع بالحال في الثيء". 20 وهو صريح قول سييويه

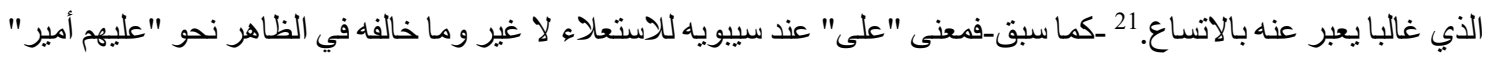

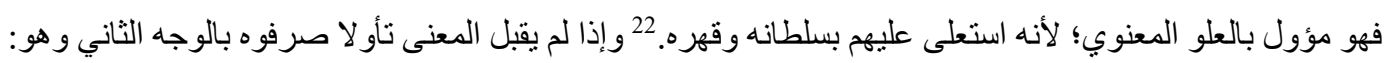

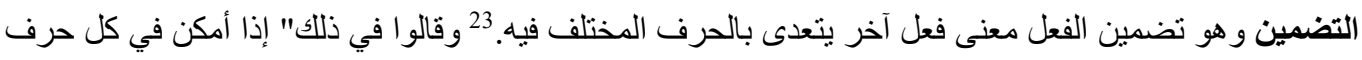

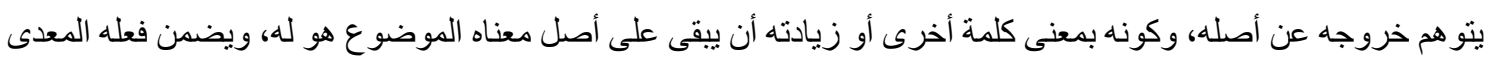

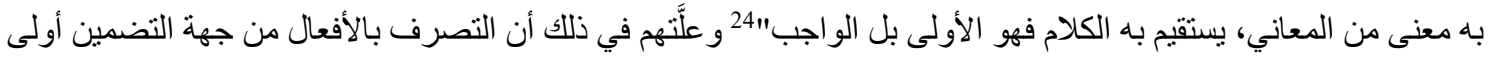
من التصرف بالحروف بجعل بعضها موضع بعض لأن الأصل ألا يتصرف بها. 25 كما في فول أبي ذؤيب الهذانلي:

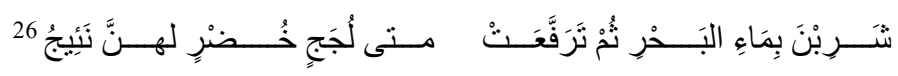

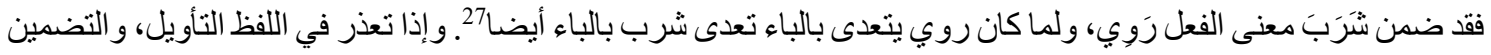
قالو ا إنَّه من باب نيابة حرف مكان حرف على الثذوذ، ولا يجري القياس فيه. وهو الوجه الثالث عند البصريين.

16 ابن هشام عبدالله بن بوسف، مغني اللبيب عن كتب الأعاريب، تحق. مازن المبارك، ط 6، (دمشق: دار ـالفكر،1985)،

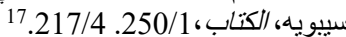
18 الحسن بن عبد الله السير افي، شرح كتاب سبيويه، تحق. أحمد مهذلي، ط1، (بيروت، دار ـالكتب العلمية،2008)، 93/5. 71/20، ألهن 19

ابن هثام عبدالله بن يوسف، مغنسي اللبيب، $151 / 20$.

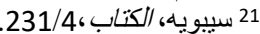

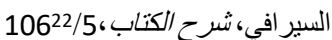

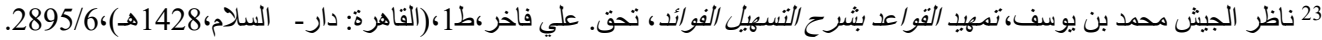

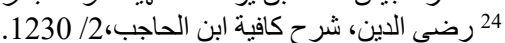

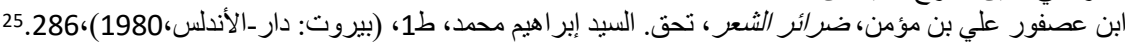

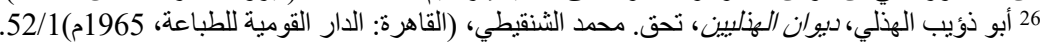

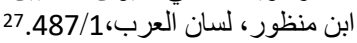

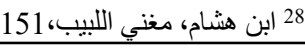


جواز النيابة بين حروف الجر وهو قول الكوفيين.29. وحُجَّتهم أن ظاهر الكلام يقتضي وضع حرف مكان حرف آخَر. ${ }^{30}$ وفاقهم من البصريين أبو الحسن الأخفش؛ في كتابه معاني القرآن. فقد صرح بجواز أن تأني إلى بمعنى مع. نحو ركَنْ

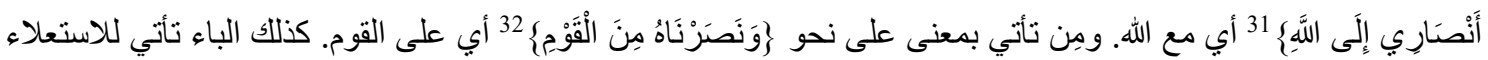

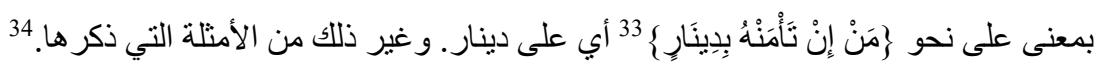
كذلك المبرد في كتابه الكامل ذهب مذهبه. فقال "وحروف الخفض يبدل بعضها من بعض، إذا وقع الحرفان في معنى

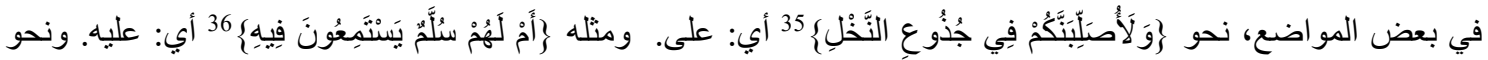

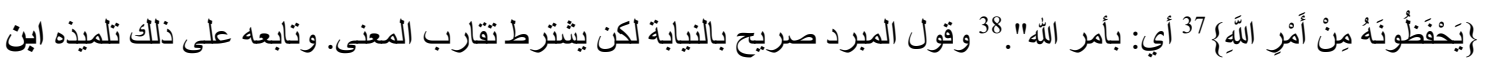

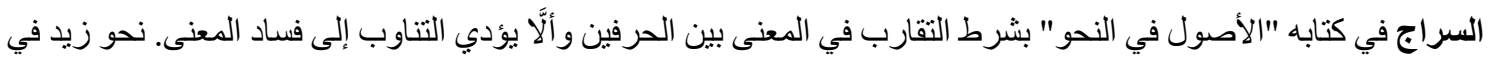
مكة وزيد بمكة فجائز. أما كتبت بالقلم وكتبت إلى القلم فغير جائز لفساد المعنى. 39 وممن قال بقول أهل الكوفة أيضا علي بن الفين محمد الهروي صاحب كتاب "الأزهية في حروف المعاني" فقد بوَب بابا في كتابه فقال "اعلم أن حروف الخفض قد يدخل بعضها مكان بعض، وقد جاء ذلك في القرآن والثعر" ثم أورد كثير ا من الثو اهد على ذلك. 40 و أخذ بقول الكوفيين كثيرٌ من علماء اللغة كابن دريد في جمهرة اللغة ب1، و وابن سيده في كتابه المخصص.

جواز النيابة ولكن بشرطو وجود المسوغ لهذه النيابة، وهو قول ابن جني في الخصائص الذي وقف موقف وسط بين المانعين و المجوزين. فقال بعد أن بوَّب في استعمال الحروف بعضها مكان بعض "هذا باب يتلقاه الناس مغسو لاً ساذجًا من فئن

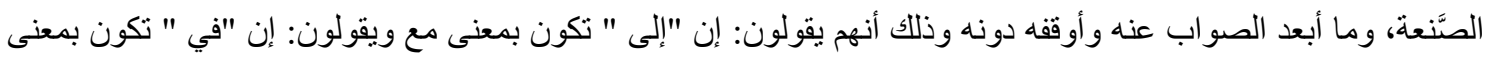

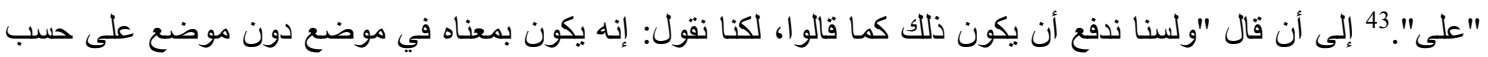
الأحو ال الداعية إليه، و المسو غة له، فأما في كل موضع و على كل حال فلا ". 44 فيكون كلام ابن جني صريح بجواز النيابة، لكن

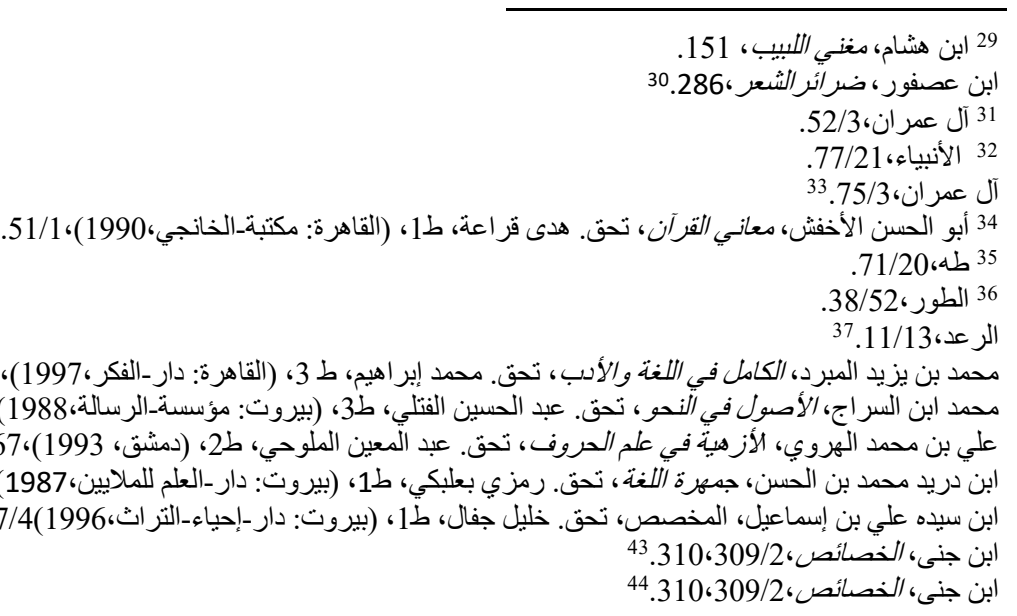


بشرط وجود المسوغ لهذه النيابة. و المسوغ عنده إذا كان هناك فعلان يحملان نفس المعنى، وكل فعل يتعدى بحرف جاز عنده

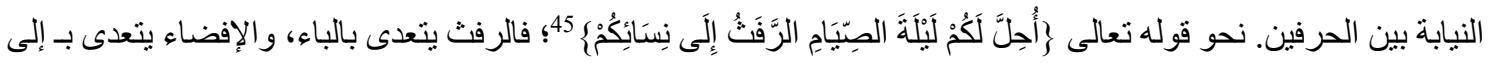
ومعنى الفعلين واحد فجاز تعدية الرفث بـ "إلى". 46 ومذهب الكوفيين بعيد عن التكلف و التعسف لذا سار أكثر المتأخرين عليه، كابن مالك، وابن هشام، والمر ادي. 47

ابن مالك من أبرز العلماء الذين تعرضو المسألة التقارض بين الحروف، فذكر ها في جُلِّ كتبه، ولا سيما شرح التسهيل، وشرح الكافية، وحتى في الألفية على صِغَرِ حجمها. وبالوقوف على كلامه يتضح أنَّه يقول بقول الكوفيين بالجملة في مسألة

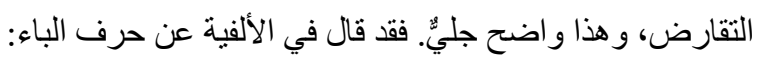

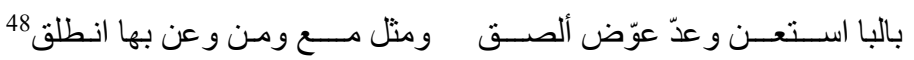
فظاهر كلامه أن الباء تنقارض مع "من، وعن، ومع" و عند كلامه حول "على وعن" قال:

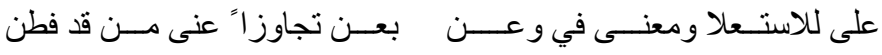

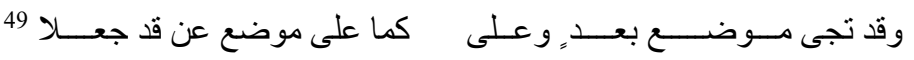

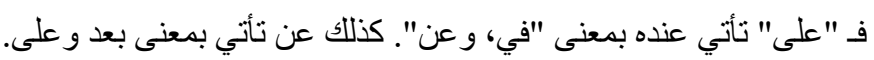

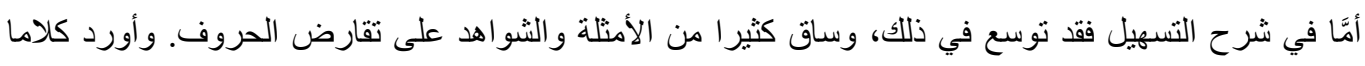

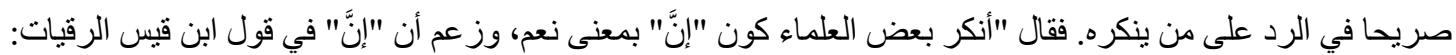

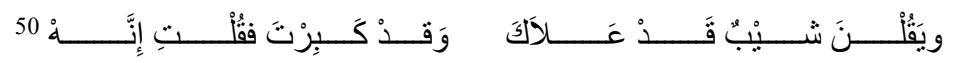
مؤكدة ناصبة للاسم رافعة للخبر ، وجعل الهاء اسمها، والخبر محذوفا" إلى أن قال" والذي زعم هذا القائل ممكن في البيت

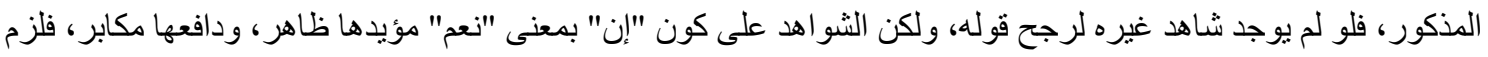

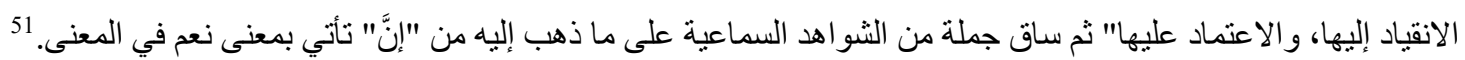

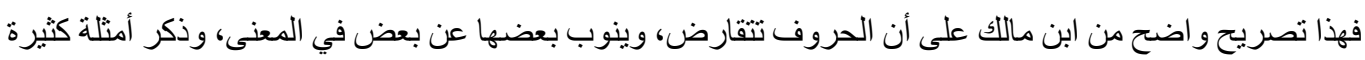

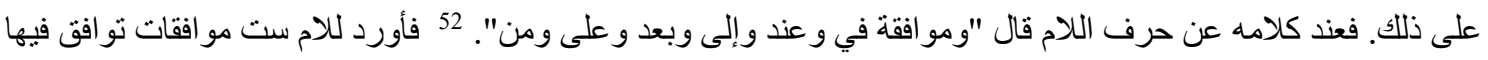


Alali-Hazer, İbn Mâlik'e Göre Harf-i Cerlerde Tekârud/Ödünç Alma اللام غير ها من الحروف في المعنى. وفي هذا كلام صر ح لابن مالك حول جو از تقارض الحروف في المعنى؛ فإن "على" تأتي

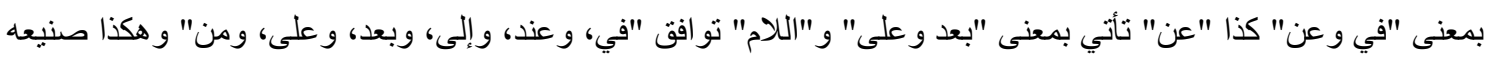
مع بقية الأحرف في باب النيابة. فيتضح أن مذهبه في هذا مذهب الكوفيين في الجملة، ويُكثِر النقل عن الفر اء مو افقة له ــكا سيأتي-. ومع هذه كله إلا أنه يقول في بعض المواضع بقول البصريين لكنها مو اضع قليلة جدا. فمن ذللك كلامه في بيت أبي

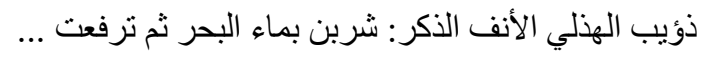

قال ابن ماللك "الأجود في هذا أن يضمن شربن معنى روين ويعامل معاملته، كما ضمن يُحمى معنى يوقد فعومل

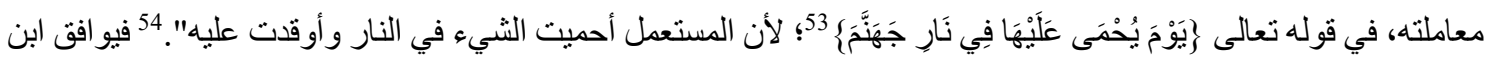
مالك البصريين على تضمين الفعل شرب معنى روي. فلا يكون فيه شيء من التقارض على هذا المعنى.

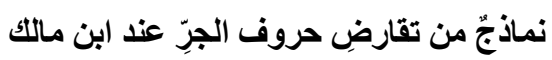

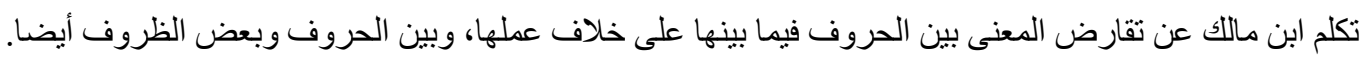
وسيقتصر البحث على التقارض بين حروف الجر فيما بينها من جهة بالدرجة الأولى. ثم بين حروف الجر وبعض الظروف من

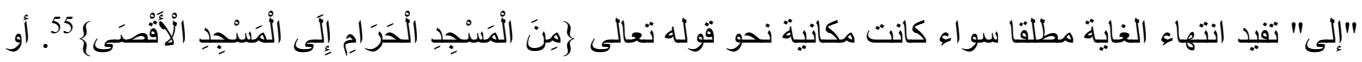

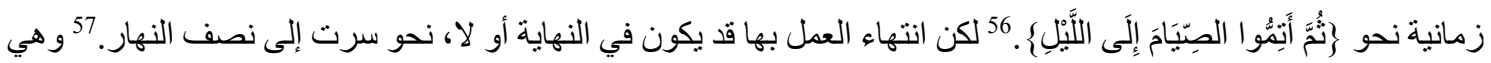

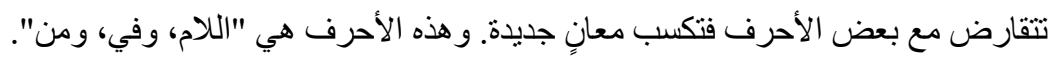

أولاً: التقارض بين "إلى "و"اللام":

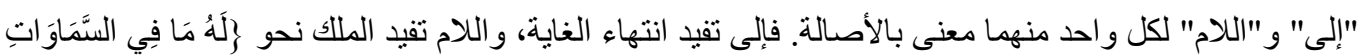

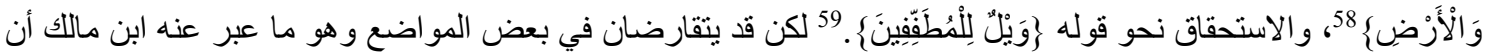

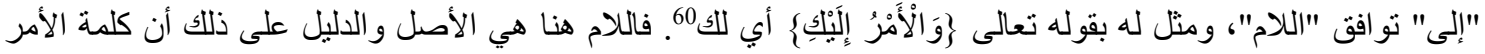

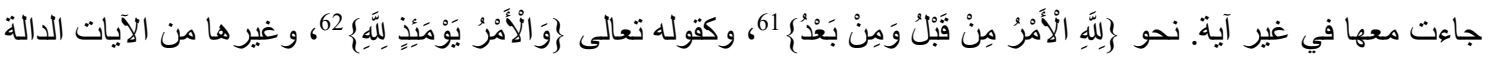

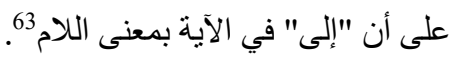

$$
\begin{aligned}
& \text { الت التوبة،35/9. }
\end{aligned}
$$

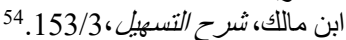

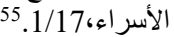

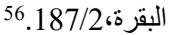

$$
\begin{aligned}
& \text { ابن مالك، شرح الكافية، 16/299/2؛ شرح التسهيل، 141/3. }
\end{aligned}
$$

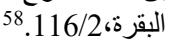

$$
\begin{aligned}
& \text { ابن مالك، شرح التسعيل، 1144/3؛ شرح الكافية، 882/2، 802، الألفية، 116. } 59
\end{aligned}
$$

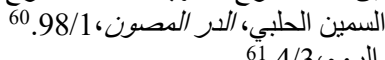

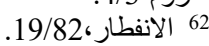


Alali-Hazer, The Phenomenon of Grammatical "Borrowing "between Prepositions by Ibn Malik

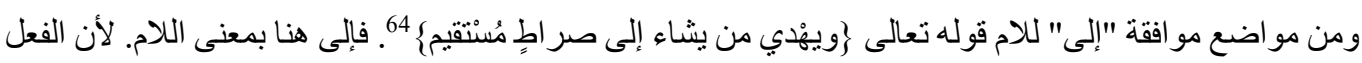

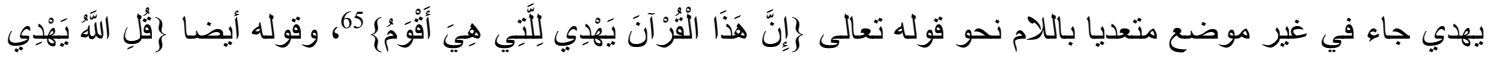

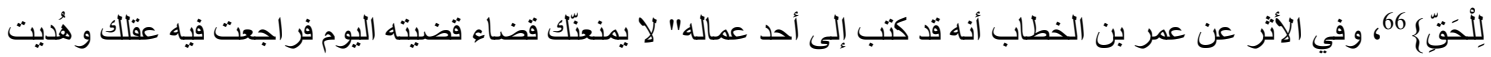
فيه لرُشدك أن ترجع إلى الحق". 67 وظاهر الأدلة التي ذكر ها ابن مالك أن الفعل هدى يتعدى باللام، فلََّ على أن "إلى" في الآية بمعنى اللام

كذلك تو افق اللام "إلى" في بعض المواضع و هو ما عبر عنه ابن مالك بقوله "مو افقة إلى" و استنل على ذلك بقوله

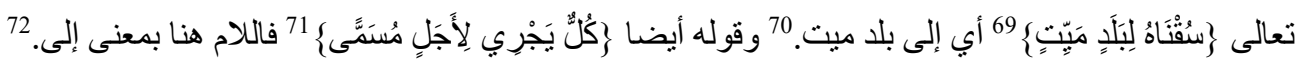

ثانيا: التقارض بين "إلى" و "في":

قد تقدم أنَّ "إلى" تفيد انتهاء الغاية الزمانية و المكانية. و "في" تفيد الظرفية ومعنى الظرف: ما يحوي الثيء كالو عاء

وما جرى مجر اه من إناء أو كيس.73 وتأتي "في" للظرفية أصالة سواء كانت ظرفية حقيقية وهي إما مكانية نحو قوله تعالى

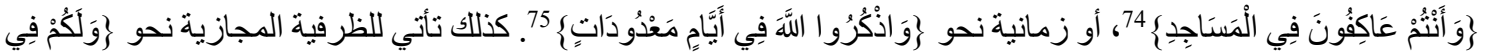

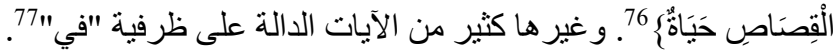

وقد تقترض "إلى" معنى الظرفية من "في" عند ابن ماللك واستدل على ذللك من النثر ، والثعر. فمن النثر قوله تعالى

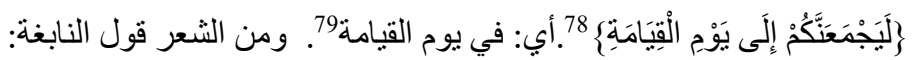

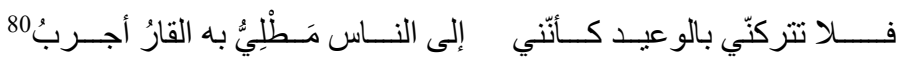

الثاهد أي: في الناس. 81 وابن مالكك من النحاة القلائل الذين ذكروا هذا المعنى بين "إلى" و "في". 82

ثالثا: التقارض بين "إلى" و "من":

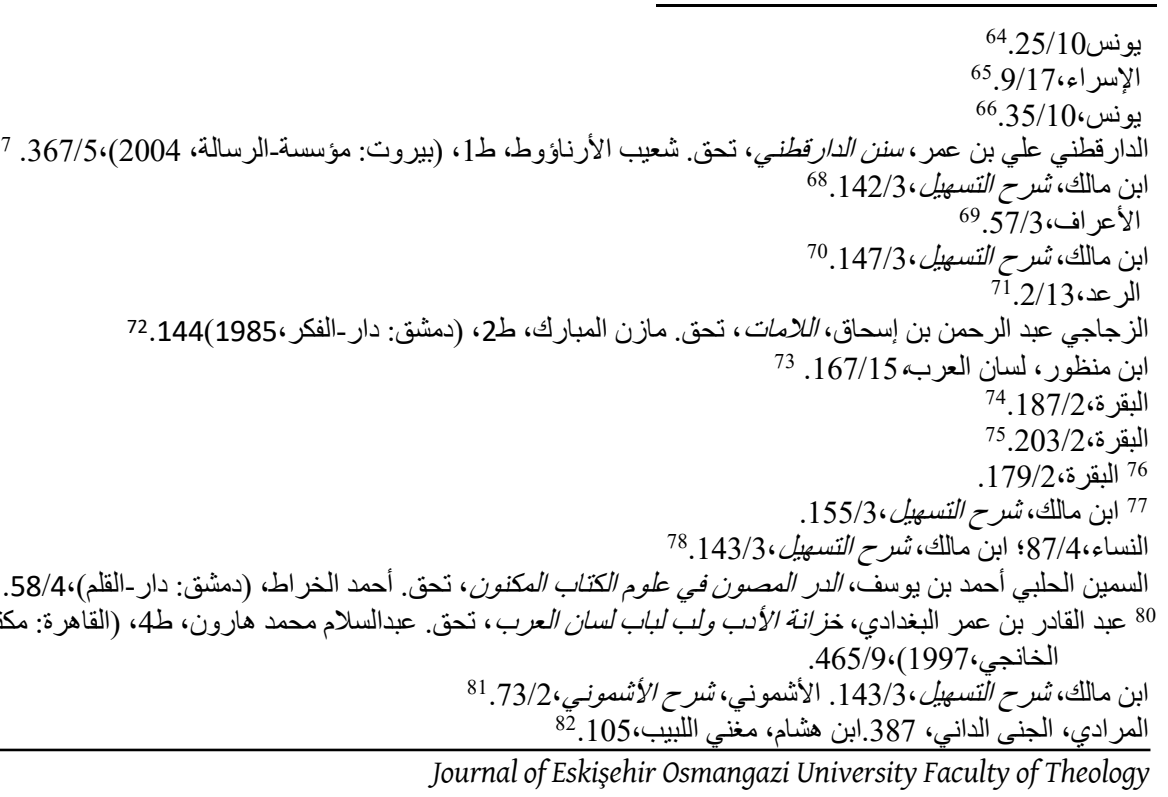


Alali-Hazer, İbn Mâlik'e Göre Harf-i Cerlerde Tekârud/Ödünç Alma

قد تأتي "إلى" بمعنى "من" فتفيد ابتداء الغاية. و استدل ابن مالك على ذلك بقول عمرو بن الأحمر:83

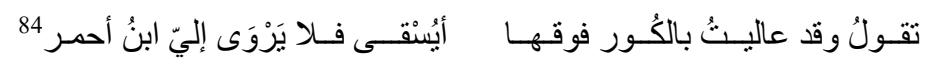

فــ "إلى "في البيت بمعنى "من" الابتدائية، أي فلا يَرَوى مني، لأن الفعل رَوِي يتعدى بـ "من" فيجري على ظاهره من تعديه بـ "من"، و أيضـا فإن الري عكس الظمأ، والظمأ متعدي بإلى نحو ظمئ إلى الماء، فتعدي رَوِي حملا على ضدها، وذاك أن العرب تجري الأشياء مجرى أضدادها. 85 وقد يكون التقارض بينهما عكسي فتأتي "من" معنى "إلى" نحو اقتربت منه أي إليه.86

الحرف الثاني "الثلام":

يعتبر حرف اللام أكثر الحروف معانٍ على الإطلاق، أوصلها البعض إلى ثناثين معنى. 87 وأثشر معانيها الملك و الاستحقاق لذا اقتصر سييويه عليهها. 88 وذكر ابن مالك لها تسعة عشر معنى. 89 وهي تتقارض عنده مع "في، وعلى، ومن، و إلى". وقد تقدم الكلام بينها وبين إلى.

\section{أولا: التقارض بين اللام وفي:}

قد تأتي "اللام" وتفيد معنى الظرفية كـ "في"، عند ابن مالك و استدل على ذلك من القرآن وكلام العرب. أما القرآن

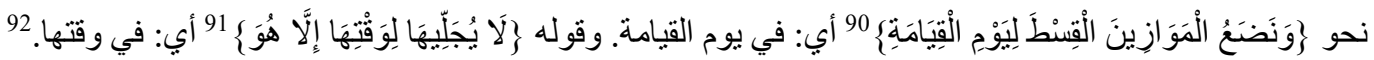
ومن الشعر قول مسكين الدارمي:

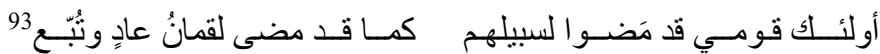

وقول الحكم بن صخر:

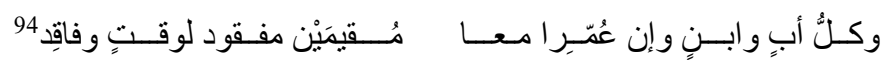

الثاهد في كلا البيتين أي: قد مضو ا في سبيلهم، ومفقود في وقت وفاقد. 95

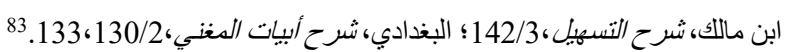

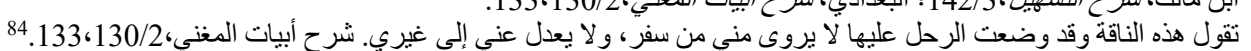

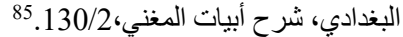

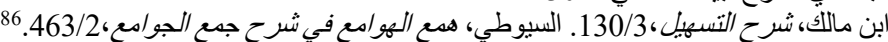

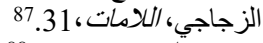

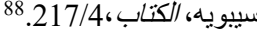

ابن مالك، شرح التسعيل، 144/3.

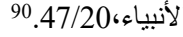

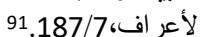

ابن مالك، شرح التسهيل،146/3. السمين الحلبي، الدر المصون،164/8، 164/3، الأشموني، شرح الأشعوني،81/2.92.

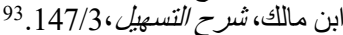

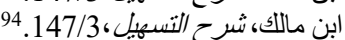

ابن مالك، شرح التسهيل، 147/3. 
كما أن "في" قد تقترض من اللام معنى التعليل، وذكر لها ابن مالك شواهد من النثر و الثعر، فمن النثر قوله تعالى

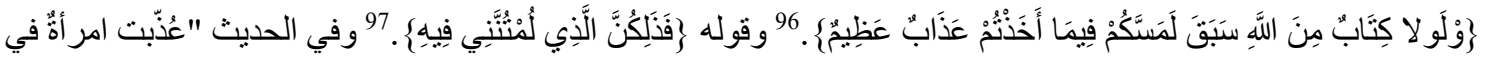
هرة". 98 ومن الثعر قول جميل بثينة:

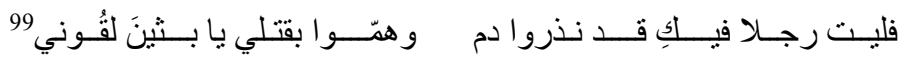$$
\text { و غير ها من الثوا هد التي ساقها ابن مالك للدالة على اقتر اض حرف الجر "في" معنى التعليل من اللام. } 100
$$

\section{ثانيا: التقارض بين "اللام" و"على":}

الأصل في معنى "على" الاستعلاء قال ابن مالك في ألفيته: "على للاستعلا...."101 وقد يقترض اللام معنى الاستعلاء

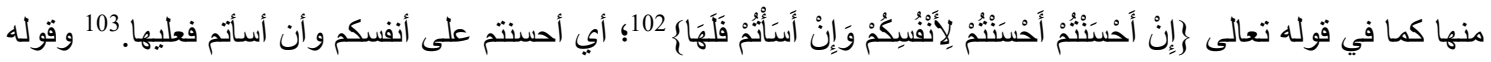

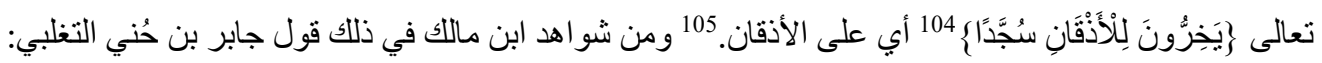

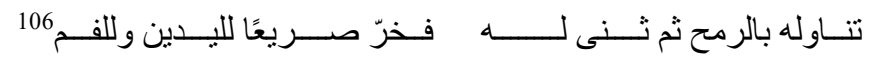

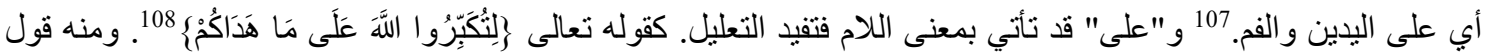
عمرو بن معد يكرب:

$$
\begin{aligned}
& \text { علامـا تقـول الرمح يتقل عاتـقـي إذا أنا لم أطعن إذا الخيـــلـ كرّت } \\
& \text { فـ"على" في البيت جاءت للتعليل بمعنى "اللام". } 110
\end{aligned}
$$

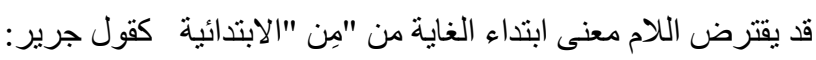

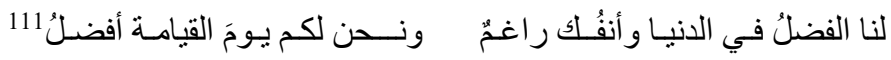

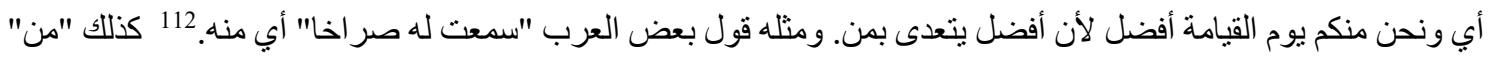

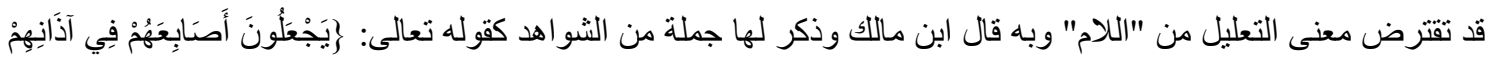

97 96 96

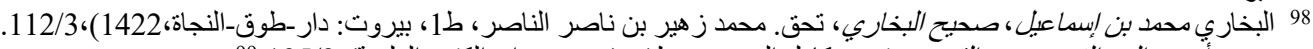

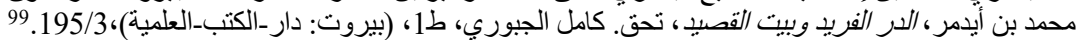

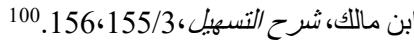

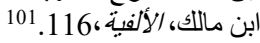

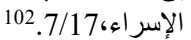

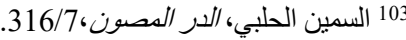

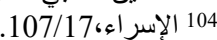

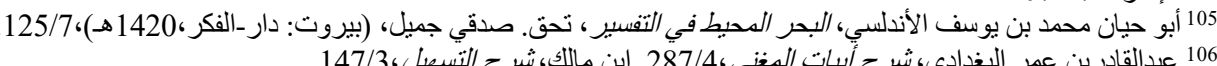

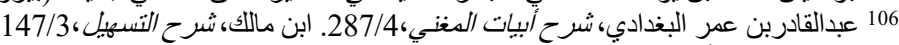

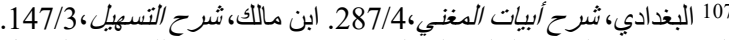

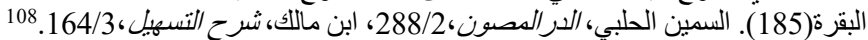

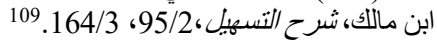

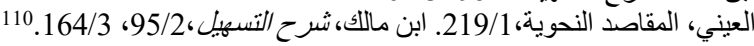

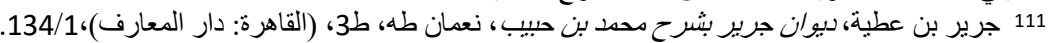

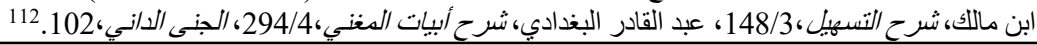


Alali-Hazer, İbn Mâlik'e Göre Harf-i Cerlerde Tekârud/Ödünç Alma

مِنَ الصَََّاعِقِيُ .113 فمن هنا للتعليل. 114 وقول عائشة عن قضاء رمضان "فما أستطيع أن أقضيَه إلّا في شعبان الشغلُ من رسول الله -صلى الله عليه وسلم-". 115 أب يمنعني الثغل لأجل رسول الله قضاءَ رمضان.

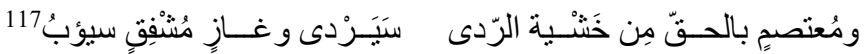

و الثاهد في البيت مجيء "من" بمعنى "اللام" أي: لخشية الردى.

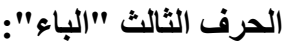

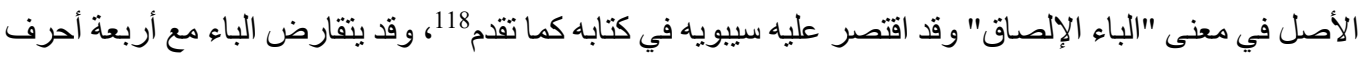

عند ابن مالك، وهي "في، وعن، ومن، و على".

أولا: التقارض بين "الباء" و"في":

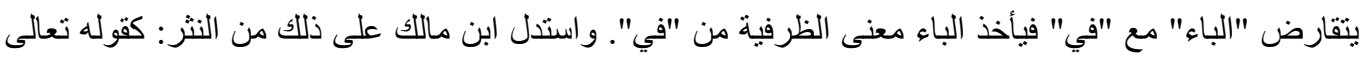

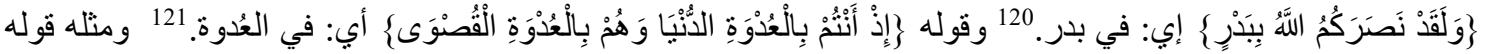

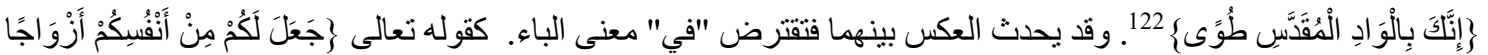

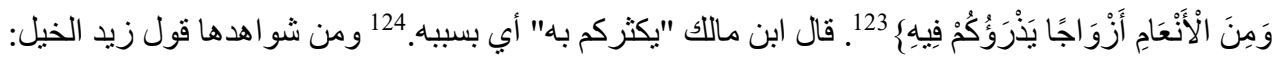

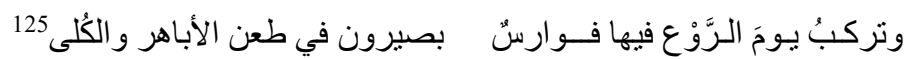

أي بصيرون بطعن.126 نقل ابن مالك عن يونس أنه حكى عن بعض العرب قولهم ضربته في السيف أي بالسيف.127

ثانيا: التقارض بين "الباء" و "عن":

الأصل في "عن" أنها للمجاوزة وهو صريح قول ابن مالك في ألفينه:

على للاسـتعلا ومــعنى في وعـن بعن تجــــــاوز اءعنى مـن قد فطن 128

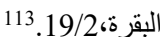

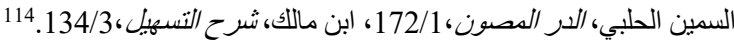

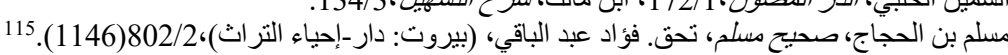

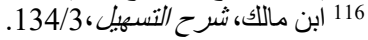

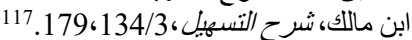

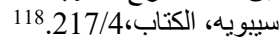

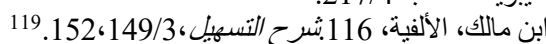

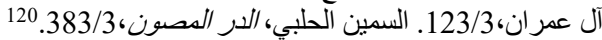

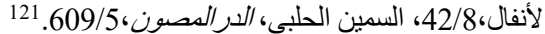

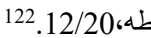

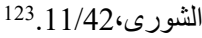

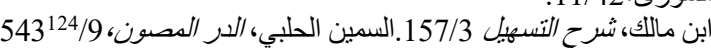

125 عبد القادر البغدادي، خزانة الأبب، 9 / 9 / 1593.

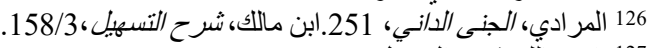

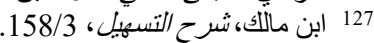

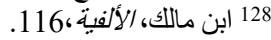


Alali-Hazer, The Phenomenon of Grammatical "Borrowing "between Prepositions by Ibn Malik

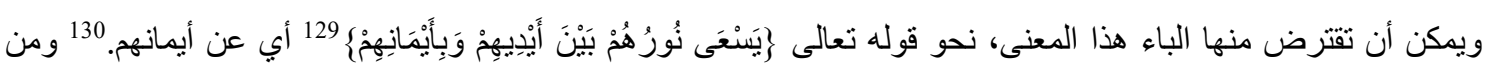
شو اهدها الثعرية: قول مرقش الأكبر:

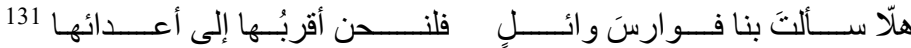
ومحل الشاهد في البيت "بنا" بمعنى "عنًّا".

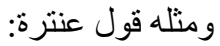

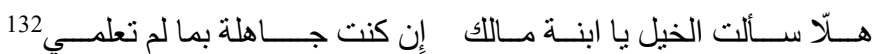

أي: عمَّا لم تعلمي.

تثالثا: التقارض بين "الباء"و"من":

"من" تفيد ابنداء الغاية ويقترض "الباء" "من" منها هذا المعنى. كما في قوله تعالى \}يشرب بها عباد اللهج أي: منها. 134

$$
\text { ومنه أيضا قول عمر بن أبي ربيعة: }
$$

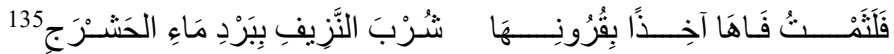

أي من برد ماء الحشر ج. نسب ابن مالك للفارسي أنه قال الباء بمعنى من في هذا البيت. 136 كذللك تأتي "من" بمعنى "الباء" قاله

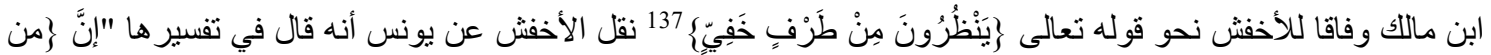

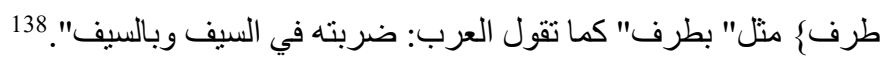

رابعا: التقارض بين "الباء" و"على":

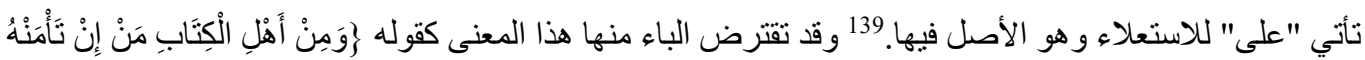

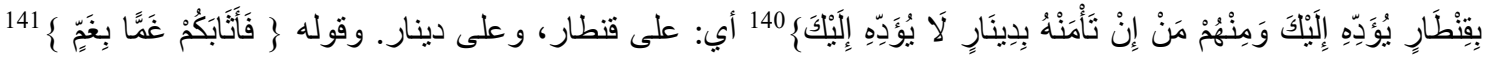
أي: غما على غر. 142 وقول ر اشند بن عبدربه:

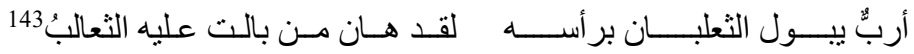

أي: على رأسه، ودليل ذلك الثطر الثاني من البيت فقد تعدى الفعل بال بـ "على". 144

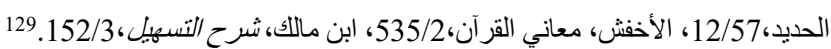

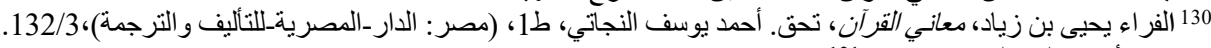

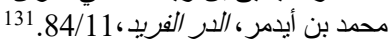

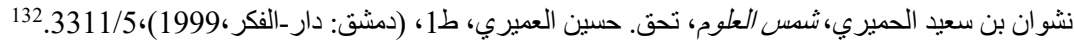

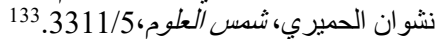

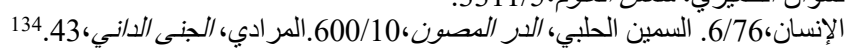

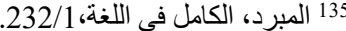

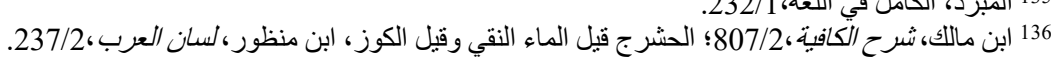

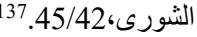

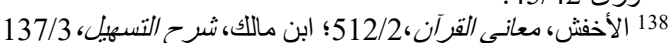

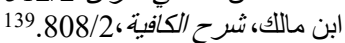

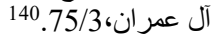

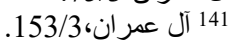

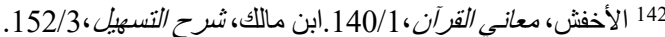

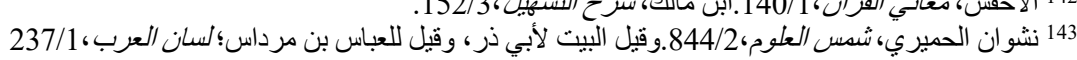

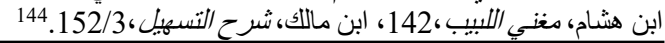


Alali-Hazer, İbn Mâlik'e Göre Harf-i Cerlerde Tekârud/Ödünç Alma

وكما أن "الباء" قد تأتي بمعنى "على" كذلك "على" تأتي بمعنى الباء. قال ابن مالك "واستعمالها مو افقة للباء نحو

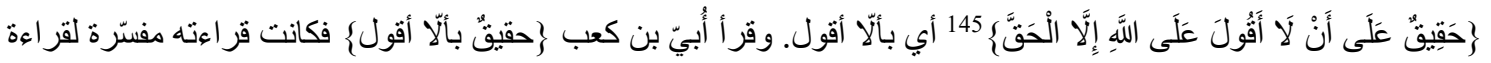

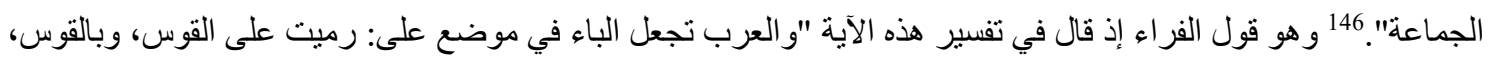

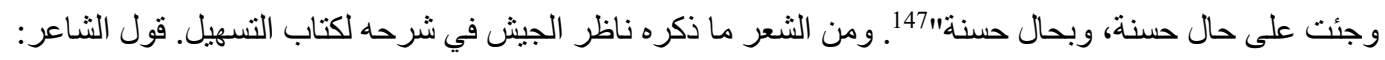

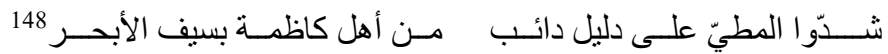
و الثاهد في البيت على تقدير: بدليل دائب.149 وقول أبي ذؤيب الهذلي:

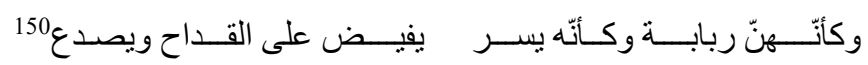
أي: يفيض بالقدح.

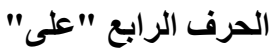
الأصل في "على" الاستعلاء كما تقدم، إلا أنه قد يقترض معان آخر من بعض الحروف وهي: "الباء، واللام" وقد تقدم الكلام عليهما، وللمجاوزة بمعنى "عن" و الظرفية بمعنى "في "و ابتداء الغاية بمعنى "من". 152 أولا التقارض بين "على" و "عن":

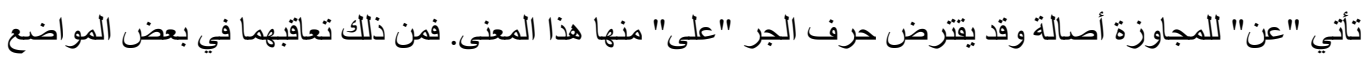

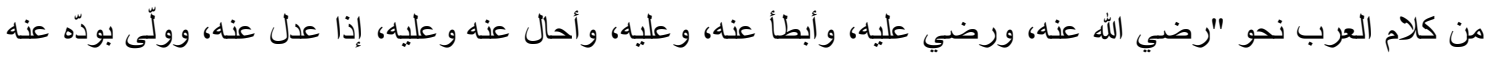
و عليه". 153 ومن شو اهد ابن ماللك الثعرية قول الأعثى:

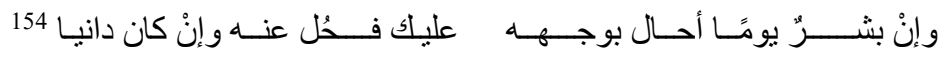
و الثاهد مجيء "على" بمعنى "عن" ودلَّ عليه الثطر الثاني إذ تعدى الفعل أحال بـ عن.

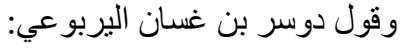

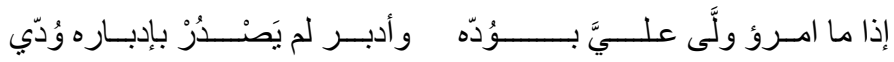

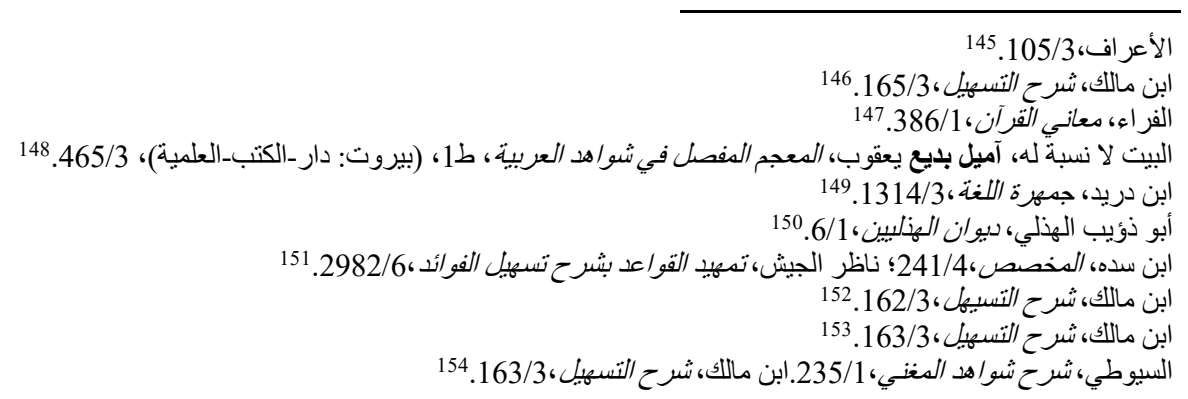


Alali-Hazer, The Phenomenon of Grammatical "Borrowing "between Prepositions by Ibn Malik

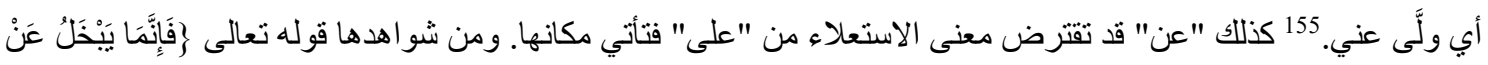

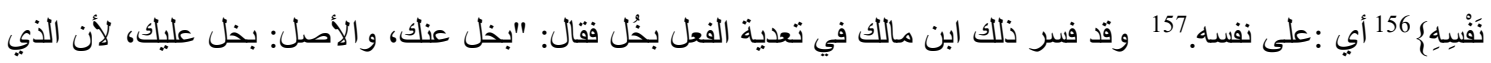

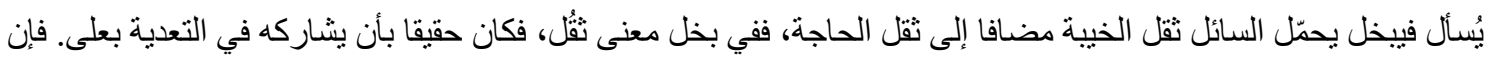
عُدّي بعن كان معناها معنى على". 158 ومن معانيها في الاستعلاء قول ذو الأصبع:

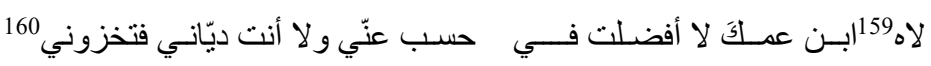

و الثاهد في البيت: لا أفضلت في حسب عليّ أي: لم بعلُ حسبك على حسبي. 161

ثانيا: التقارض بين "على" و"في": تأتي "في" للظرفية أصالة كما تقدم، وقد تقترض "على "على" منها هذا المعنى. وبه قال ابن مالك وفاقا للفراء في قوله

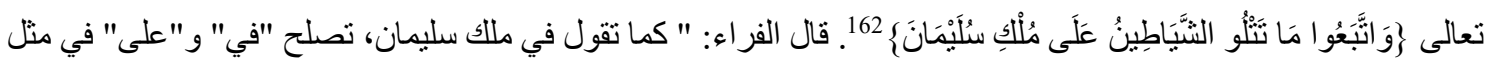
هذا الموضع تقول: أتيته في عهد سليمان و على عهله سواء". 163 ومن شو اهد ابن ماللك الثعرية:

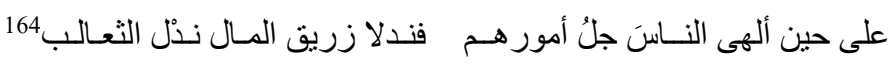

ومحل الثاهد "على حين" أي: في حين ألهى الناس. 165 كذلك تأتي "في" بمعنى "على" مستقرضة معنى الاستعلاء منها. واستدل

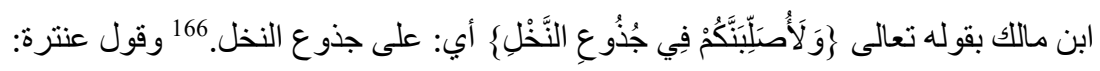

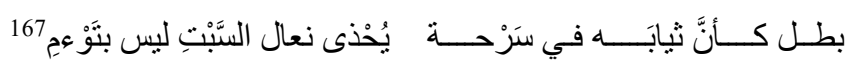

ثالثا: التقارض بين "على" و "من":

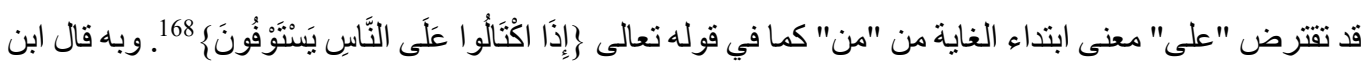

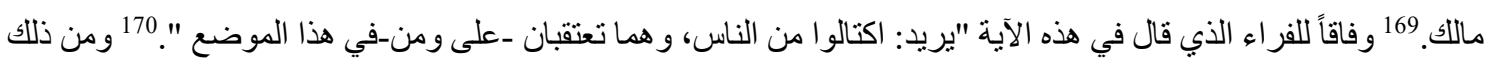

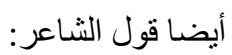

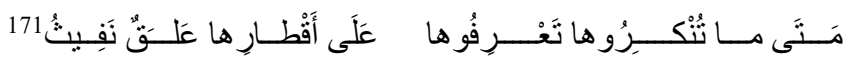

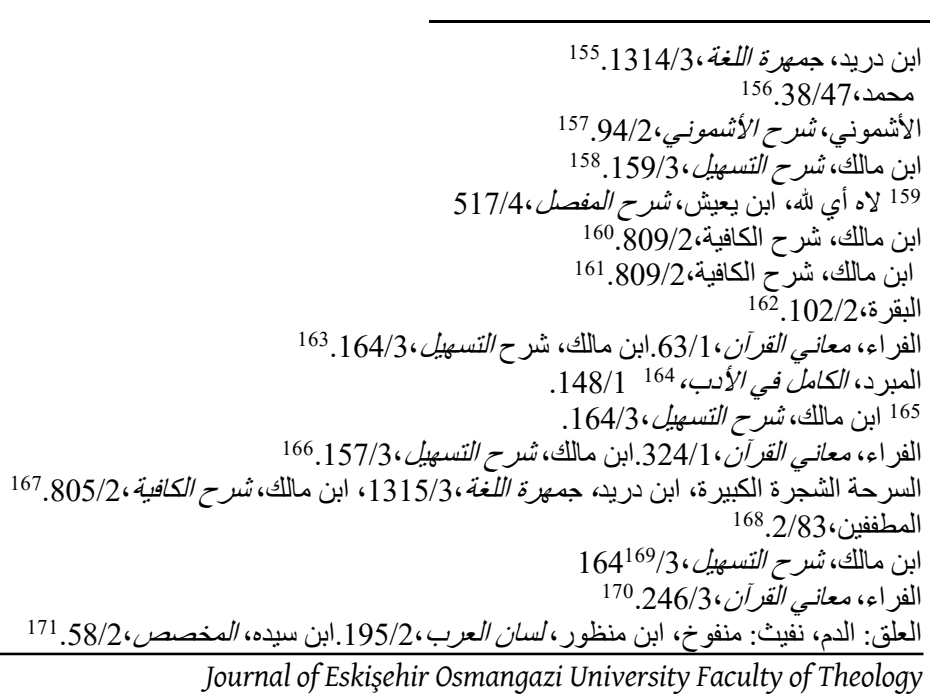


Alali-Hazer, İbn Mâlik'e Göre Harf-i Cerlerde Tekârud/Ödünç Alma

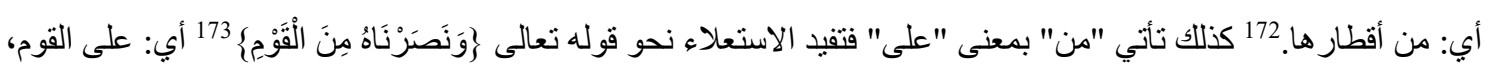

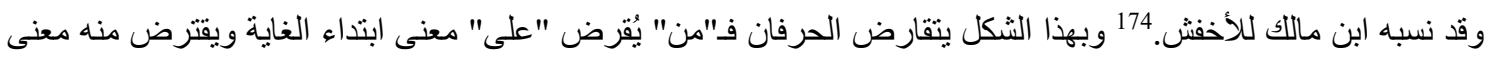

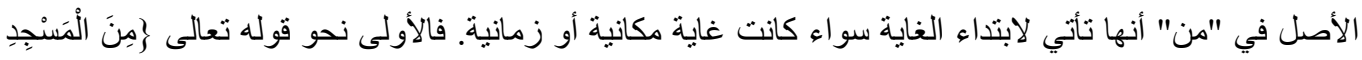

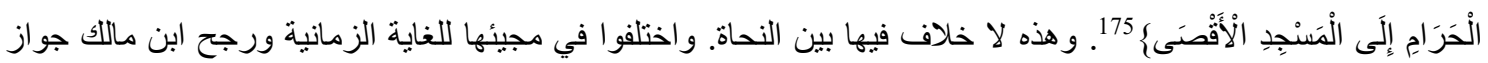
ذلك. 176

وقد تأتي لمعانٍ أخرى، منها مو افقة بعض حروف الجر بالمعنى؛ كالتعليل، والاستعلاء، وموافقة الباء، وإلى ـوقد تقدمت و المجاوزة، وفي.

\section{أولا: التقارض بين "من" و "عن":}

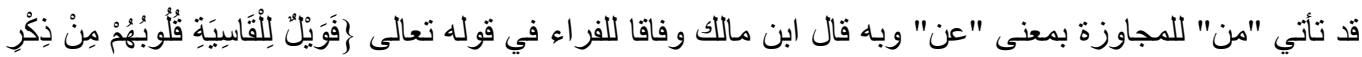

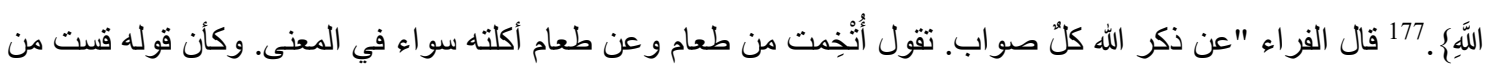
ذكره أنهم جعلوه كذبا فأقسى قلوبهم زادها قسوة. وكأن من قال: قست عنه يريد: أعرضت عنه". 178 ولمعنى المجاوزة جاءت

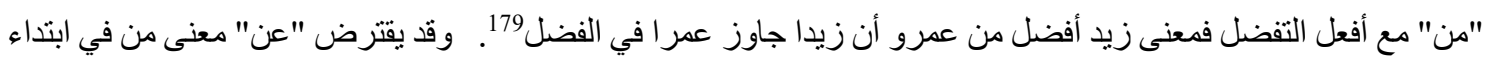

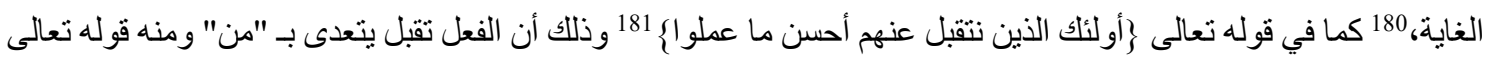
182 . 182$\}$

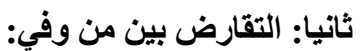

قد تُقرِ "في" معنى الظرفية لـ "من" في بعض المو اضع كقول وضاح بن إسماعيل:

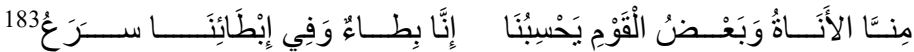

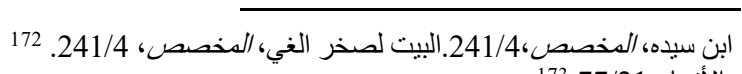

$$
\begin{aligned}
& \text { الأنبياء، 77/21. }
\end{aligned}
$$

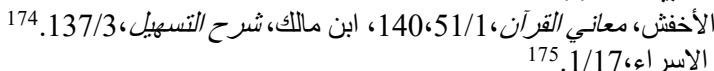

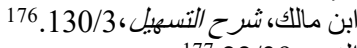

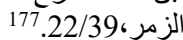

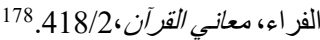

$$
\begin{aligned}
& \text { ابن مالك، شرح التسعيل،135/3.179، } 179 \\
& \text { الأشموني، شرح الأشموني، }
\end{aligned}
$$

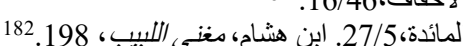

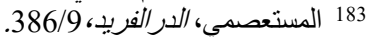


Alali-Hazer, The Phenomenon of Grammatical "Borrowing "between Prepositions by Ibn Malik

أي: فينا الأناة. 184 ومجيء من للظرفية هو اختيار ابن مالك وفاقاً للكوفيين185 واستدل أيضا بقول عدي بن زيد:

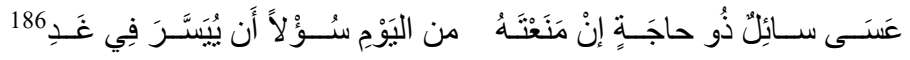

أي: في اليوم.187

المرف السادس "(الكاف":

قد يقترض الكاف من "على" معنى الاستعلاء، وهو من اختيار ات ابن مالك ذكر ذلك في شرح التسهيل، وعزاه للفر اء. ومثل له

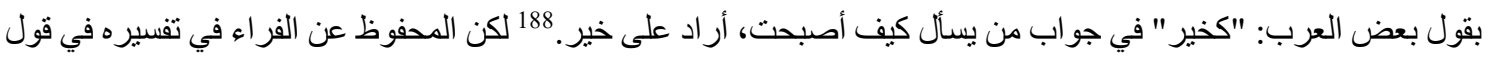

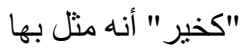
على زيادة الكاف. 189 وقيل هو لتشبيه بتقدير محذوف "كصاحب خير". 190 فلا يكون فيه شيءٌ من التقارض. التقارض بين حروف الجر والظروف: تقترض بعض حروف الجر معان من أسماء فتؤدي نفس معانيها. و غالبا تكون هذه الأسماء هي الظروف "مع، وعند،

قد تقترض إلى معنى "مع"؛ وذلك إذا ضُمُّ الثيء إلى الثيء ولم يكن معه نحو "الذود إلى الذود إبل" 191. جاء زيد ومعه مال كثير ؛ فلا يصح إليه مال كثير.

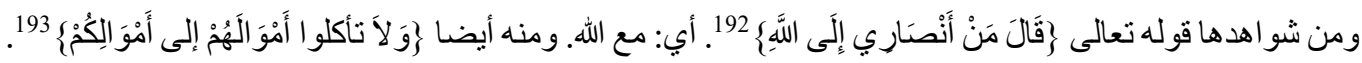

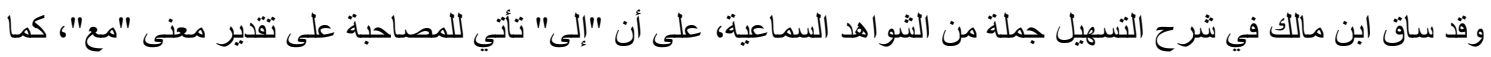
عزا هذا القول إلى الفراء. 194 ومن هذه الثو اهد قول كثير عزة:

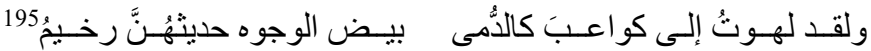
أر اد الثناعر : قد لهوت مع كو اعب.196

184

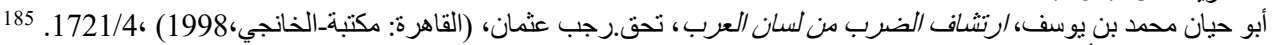

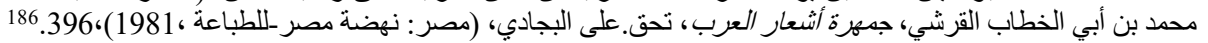

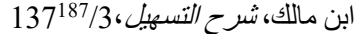

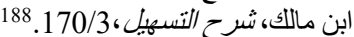

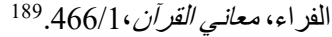
الإد 190

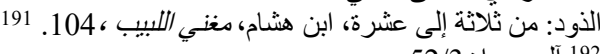
192

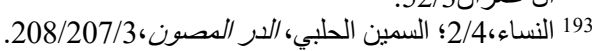
194

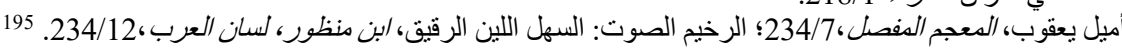
196 ابن مالك، شرح التسعيل، 141/3. 
Alali-Hazer, İbn Mâlik'e Göre Harf-i Cerlerde Tekârud/Ödünç Alma

قد نأتي "الباء" للمصاحبة مقترضة المعنى من "مع"، و علامتها أن يحسن في موضعها كلمة "مع" وتغني الحال عنها،

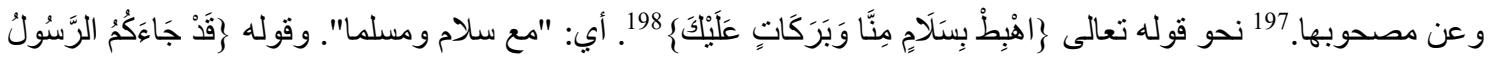
بِالْحَقِ) 199 أبي: مع الحق ومحقا. 200

ثالثا: "في" و "مع":

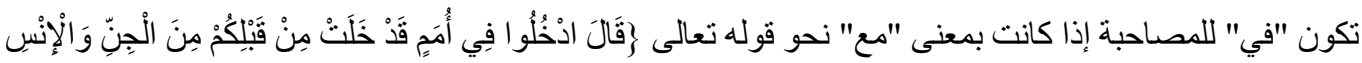

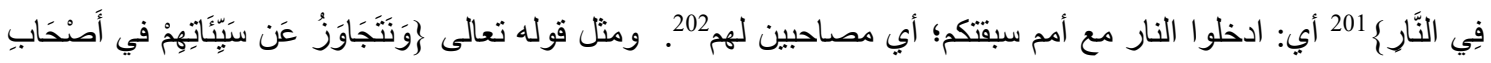
الجنةج أي: مع أصحاب الجنة. 203 وقول الثاعر:

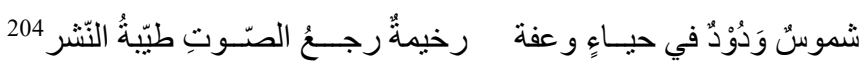

أي: ودود مع حياء و عفة. 205 فجاءت "في" بمعنى المصاحبة مقترضة هذا المعنى من "مع".

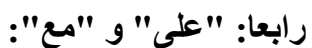

قد تأخذ "على" معنى المصاحبة من "مع" نحو قوله تعالى \}الْحَمْدُ للِّهِ اللَّذِي وَهَبَ لِي عَلَى الْكِبرِ وقول النبي-عليه الصلاة والسلام-عندما استأذن عثمان فقال" إيذن له وبشره بالجنة على بلوى تصيبه"207. أي مع بلوى. 208

خامسا: "اللام" و"عند":

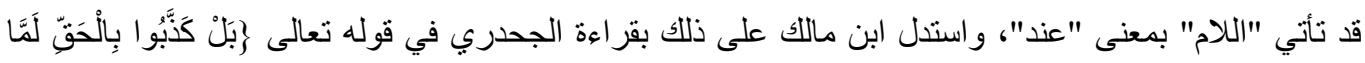
جَاءَهُجْ 209 بكسر اللام وتخفيف الميم. أي: عند مجيئه إياهم. و ابن مالك قال ذلك وفاقا لابن جني في "المحتسبـ"210" في تفسير الآية حيث قال" معنى "لما جاءهم"، أي: عند مجيئه إياهم، كقولك أعطيته ما سأل لطلبه، أي: عند طلبه ومع طلبه، وفعلت هذا

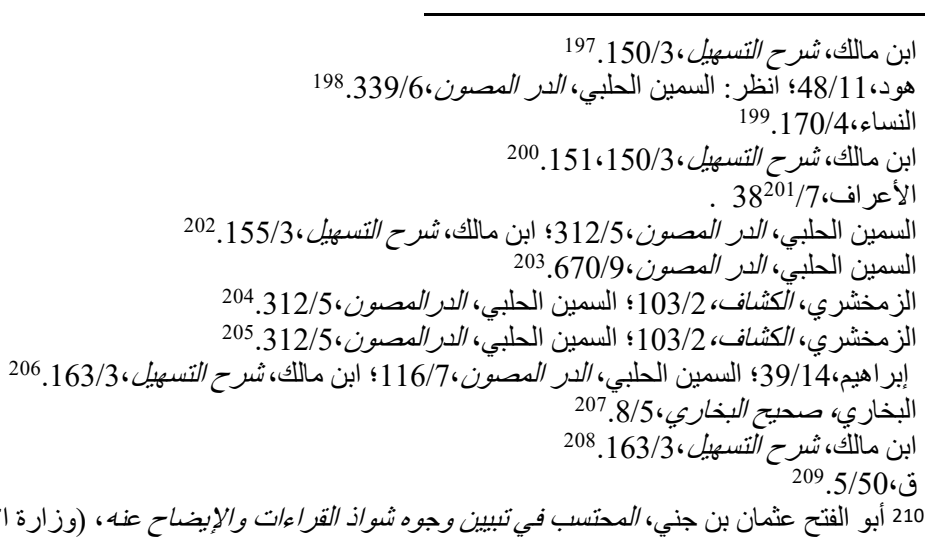

210 أبو الفتح عثمان بن جني، المحتسب في تبيين وجوه شواذ القراءات والإيضاح عنه، (وزارة الأوقاف_المجلس الأعلى للشئون

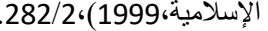


Alali-Hazer, The Phenomenon of Grammatical "Borrowing "between Prepositions by Ibn Malik

لأول وقت، أي: عند ومعه، وكقولك في التاريخ: لخمس خلوان، أي: عند خمس خلوان، أو مع خمس خلوان". 211 ومنه قول مالك بن الحارث الهذلي:

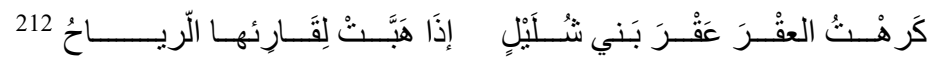

أي: عند وقتها.

سادسا: "اللام" و"بعد":

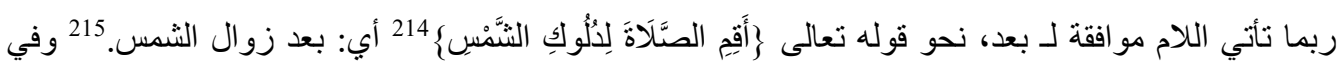

الحديث "صومو الرؤيته، و أفطرو الرؤيته"216 أي: بعد رؤيتها217. واستدل ابن مالك على ذلك من الثعر بقول متمم بن نويرة:

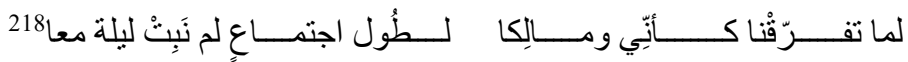

أي: بعد طول اجتماع.219

سابعا: "عن" و "بعد":

قد تأتي "عن" مو افقة لـ "بعد" في المعنى. ذكره ابن ماللك في شرح التسهيل مو افقا للفر اء في قوله تعالى ركلَتَرْبَنَّ

طََبقًا عَنْ طَبَقِي 220 قال الفر اء "حالا بعد حال". 221 ومن شو اهد ابن مالك الشعرية قول الحارث بن عباد:

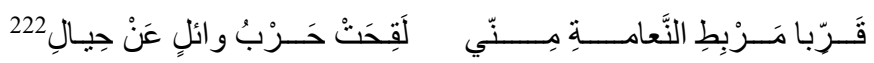

أي: بعد حيال. 223 ومثله قول الأعشى 224:

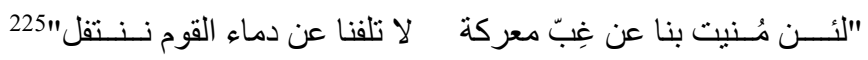

أي بعد غِبّ معركة226. و اقتر اض عن لهذا المعنى قليل 227.

فهذا من جملة ما ذكره ابن ماللك في تقارض الحروف -نيابة بعضها مكان بعض في المعنى -ويمكن القول إنَّ ابن

مالك توسع في ذللك اتباعا للسماع، فلم يقول بنيابة حرف مكان حرف إلا بدليل من السماع نثر ا، أو شعر ا. و الأخذ بقول من سبقه

ابن مالك، شرح التسعيل، 2147/3؛ ابن جني، المحتسب، 283/3.

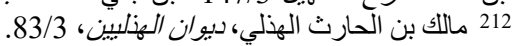

ابن جني، المحتسب، 282/213.

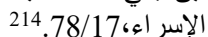

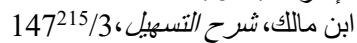

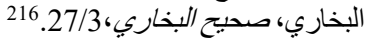

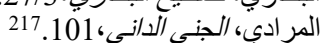

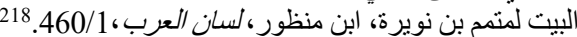

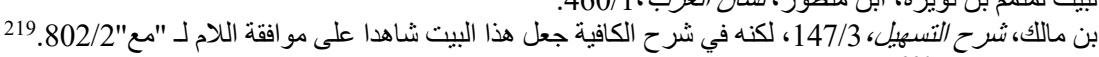

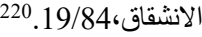

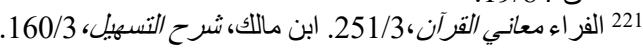

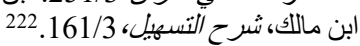

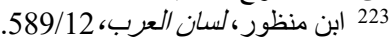

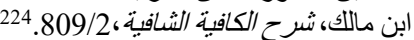

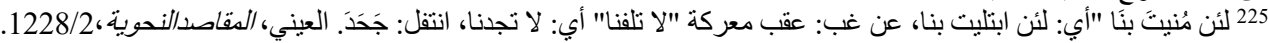

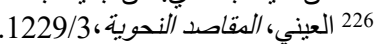
227 ابن مألك، شرح الكافية الثافية، 809/2 
Alali-Hazer, İbn Mâlik'e Göre Harf-i Cerlerde Tekârud/Ödünç Alma من النحاة على اختلاف مدارسهم. فهو ينقل عن أبي الحسن الأخفش من البصريين، وعن الفراء من الكوفيين. ولم يأب بمن يخالف إذا قام عنده الدليل -بنيابة الحروف عن بعضها-ويناقش حجج من ينكر ذلك ويرد عليهم مع إجلاله لهم.

\section{نتائج البحث:}

تعتبر ظاهرة التقارض بين حروف الجر من المسائل الخلافية بين النحاة. فالبصريون منعوها وما جاء بخلاف ذللك تاؤَّلوه تأويلا يقبله اللفظ، أو على تضمين الفعل معنى فعل آخر يتعدى بذلك الحرف، أو حكموا عليه بالثذوذ. أما الكوفيون فقالو ا بالتقارض، وبه قال بعض البصريين، و استدلو ا على ذلك بكثثر من الأدلة السماعية التي لا تقبل تأو لا بحال. ومن مذهبهم استفاد أغلب النحاة المتأخرين وساروا عليه. كابن يعيش، وابن مالك، و المر ادي، وابن هشام، و غير هم كثير.

وقد وافق ابن مالك الكوفيين ودعم أقو اله بالسماع، فيبدأ بالاستدلال من القرآن، ثم بكلام العرب من نثر وشعر. ويعزز أر اءه بأقو ال الأكابر من النحاة، بغض النظر عن مذا هبهم. و غالبا ما يكون التقارض عكسي عند ابن مالك بحيث يأخذ الحرف معنى من حرف ويعطيه معناه. وربما أخذ منه معنى من غير أن يعطيه. كذلك قد تقترض حروف الجر معان من بعض الظروف.

التقارض يكون للحروف التي هي عاملة للجر بالأصسالة أمّا التي تعمل الجر تارة، وآخرى لا تعمله فلم يذكر لها ابن مالك شيئا من التقارض ك: حاثنا وخلا و عدا و غير ها. فالظاهر أن التقارض حالة شائعة في كلام العرب، لكثرة الشو اهد على ذلك وكثرة من قال به. وهو يكسب اللغة العربية سعة، ويمنح المتكلم مرونة ولا سيما في مو اطن الضرورة. 
أبو حيان محمد بن يوسف الأندلسي، البحر المحيط في التفسبر، تحق. صدقي جميل، بيروت: دار ـالفكر،1420ه، الأجز اء:10. ـ ارتشاف الضرب من لسان العرب، تحق. رجب عثمان، القاهرة: مكتبة_الخانجي، 1998، ج5. أبو القتح عثمان بن جني، المحتسب في تبيين وجوه شواذ القراءات والإيضاح عنه، وزارة الأوقافـالمجلس الأعلى للثئون الإسلامية، 1999، الأجزاء:2.

ـ الخصائص، الطبعة الر ابعة، مصر : الهيئة ـالمصرية ـالعامة_للكتاب. الأجز اء:3. الزمخثري أبو القاسم محمود بن عمرو بن أحمد، المفصل في صنعة الإعراب، تحق. علي بو ملحم، الطبعة الأولى، بيروت:

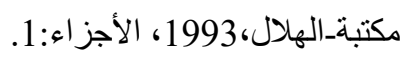

أبو بكر محمد بن الحسن بن دريد، جهرة اللغة، تحق. رمزي بعلبكي، الطبعة الأولى، بيروت: دار-العلم للملايين،1987. أبو زيد محمد بن أبي الخطاب القرشي، جهرة أشعار العرب في الجاهلية والإسلام، تحق.على البجادي، مصر : نهضة مصر-

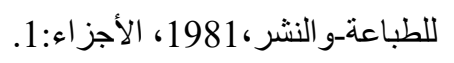

أبو بكر محمد بن السري ابن السراج، الأصول في النحو، تحق. عبد الحسين الفتلي، الطبعة الثالثة، بيروت: مؤسسةـ

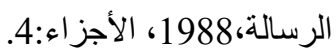

أحمد بن فارس الرازي، مجمل اللغةة، تحق. زهير سلطان، الطبعة الثانية، بيروت: مؤسسة_الرسالة،1986، الأجز اء:2. السمين الحلبي أحمد بن يوسف، الدر العصون في علوم الكتاب المكنون، تحق. أحمد محمد الخراط، (دمثق: دار-القلم)،

$$
\text { الأجز اء:11. }
$$

آميل بديع يعقوب، الدعجم الدفصل في شو/هد العربية، الطبعة الأولى بيروت: دار ـالكتب_العلمية،1996، الأجز اء:14. العيني بدر الدين محمود بن أحمد، لمقاصد النحوية في شرح شو/هد شروح الألفية، تحق. علي محمد فاخر، أحمد محمد نوفيق السوداني، عبد العزيز محمد فاخر، الطبعة الأولى، القاهرة: دار ـالسلام،2010، الأجزاء:4." رضي الدين الاسترابادي، شرح الرضسي لكافية /بن الحاجب، تحق. يحيى مصري، الرياض: جامعة_محمد بن سعود،1996.

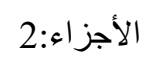

سعيد بن مسعدة أبو الحسن الأخفش الأوسط، معانسي القرآن، تحق. هدى قر اعة، القاهرة: مكتبة_الخانجي،1990، الأجز اء:3. سيبويه، عمرو بن عثمان، الكتاب ، تحق. عبد السلام محمد هارون، الطبعة الثالثة، القاهرة: مكتبة_الخانجي،1988م. الأجزار :4. نشوان بن سعيد الحميري، شعس العلوم ودواء كلام العرب، تحق. حسين العميري، الطبعة الأولى، دمشق: دار ـالفكر،1999.

$$
\text { الأجز اء:11. }
$$

عبد الرحمن بن إسحاق البغدادي الزجاجي، أبو القاسم -، اللامات، تحق. مازن المبارك، الثانية، دمشق: دار ـالفكر،1985.

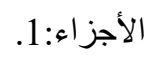

عبد الرحمن بن أبي بكر، السيوطي، شرح شو/هد المغني، تحق. أحمد ظافر كوجان، لجنة_التراث_العربي،1996، الأجز اء:2. عبد القادر بن عمر البغدادي، شرح أبيات مغني اللبيب، تحق. عبد العزيز رباح ـأحمد يوسف دقاق، الطبعة: ج 1-4الثانية، ج

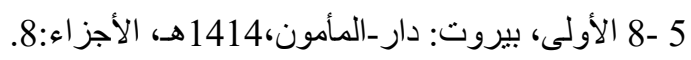


Alali-Hazer, İbn Mâlik'e Göre Harf-i Cerlerde Tekârud/Ödünç Alma علي بن إسماعيل بن سيده، الدخصص، تحق. خليل جفال، الطبعة الأولى، بيروت: دار -إحياء -التراث_العربي،1996، الأجز اء:5 الاعن

علي بن عمر الارارقطي، سنن الدارقطني، تحق. شعيب الأرناؤوط، حسن عبد المنعم شلبي، عبد اللطيف حرز الله، أحمد بر هوم، الطبعة الأولى، بيروت: مؤسسة_الرسالة، 2004، الأجزاء:5.

علي بن محمد الأثثوني، منهج السالك إلى ألفية /بن مالك، الطبعة الأولى، بيروت: دار -الكتب_العلمية، 1998م، الأجز اء:4.

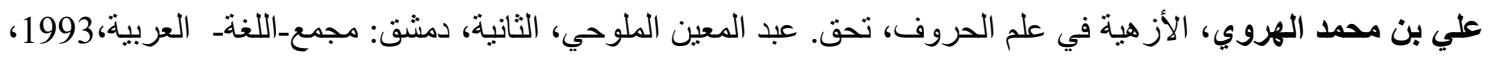

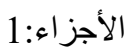

محمد ابن مالك، جمال الدين، شرح الكافية الشافية، تحق. عبد المنعم أحمد هريدي، الطبعة الأولى مكة: جامعة أم القرى-مركز

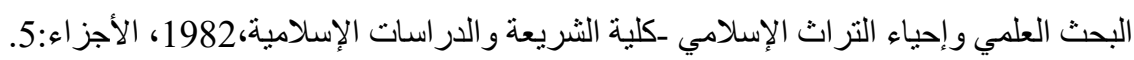
ـشرح تسهيل الفوائد، تحق. عبد الرحمن السيد، محمد بدوي المختون، الطبعة الأولى مصر: هجر-للطباعةـ

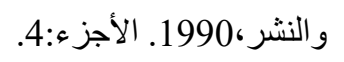

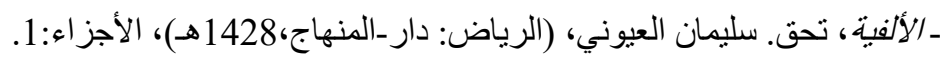

محد بن إسماعيل البخاري، صحيح البخاري، تحق. محمد زهير بن ناصر الناصر، الطبعة الأولى، بيروت: دار-طوق-

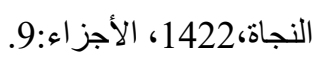

محمد بن مكرم بن منظور الإفريقي، لسان العرب، الطبعة الثالثة، بيروت: دار -صادر،1414هـ، الأجزاء:15.

محمد بن يزيد المبرد، الكامل في اللغة والأب، تحق. محمد إبراهيم، الطبعة الثالثة، القاهرة: دارـالفكر -العربي،1997،

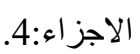

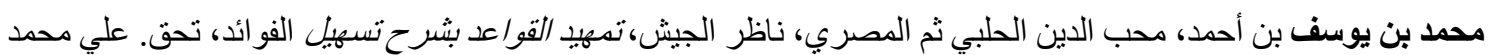

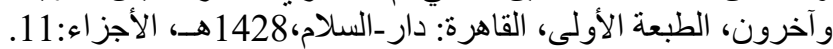

مسلم بن الحجاج أبو الحسن القتيري النيسابوري، صحيح مسلم، تحق. محمد فؤاد عبد الباقي، الطبعة الأولى، بيروت: دار -

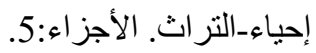

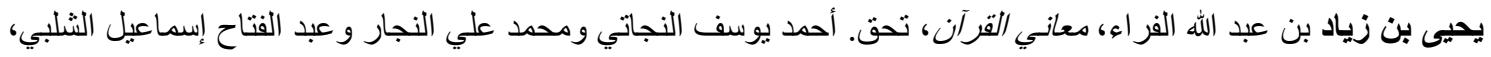

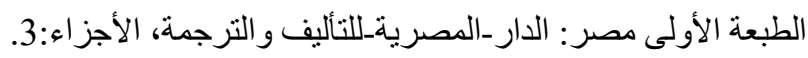

يعيش بن علي بن يعيش، أبو البقاء، ابن يعيش، شرح الدفصل للزمخشري، تحق. آميل يعقوب، الطبعة الأولى، بيروت: دار -

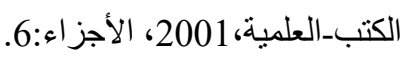




\section{Kaynaklar}

Al-Kurōn Al-Karīm

Abū Ḥayyān, Muhammad b. Yūsuf al-Andālusi. al-Baḥr al-muhit fi al- tafsīr. ed. Șidḳi Jamil.10 Volumes. Beyrūt: Dār Al-Fikr 1420 A.H. .

-Irtshāf Al-Ḍarb-Min-lisān Al-Arab. ed. Rajab 'Asmān. 5 Volumes. Cairo: Dār -al-Khanji, 1998.

Ibn Jinni, Abū'l-Fatḥ 'Asmān. al-Muhtasib, 2 Volumes. Msr: Vizārat al'avḳāf,1999.

al-Hașāyiș,3 Volumes. Msr: al-hayyat al-misriah al-óōmt llkitāb.

Al-Zamahşari Abū al-Ḳ̄āsim Mahmoūd b. 'Amrū.al-mufșal fi- șanót al-iórāōbi, ed. Ali Bū Melhim.1 Volumes, Beyrūt: mktbt-al-ḩl̄̄l,1993.

Ibn Dūraīd Muhammad b. al-Ḥasan. Jamhrat al-lag̉at, ed. Ramzi Munīr Bơlbakī, Beyrūt: Dōr al-Álam lilmalayīn,1.Edition,1987.

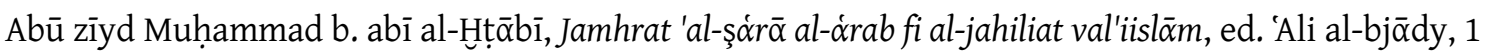
Volumes. Msr: nahșat msr-llțbớt- v al-naşir,1981.

Abū Bakr, Muḥammad b. Al-Sirri, Ibn al-Sarrōj. al-Ușūl fi al-naḥvū, ed. Abdel-Ḥussaīn al-Fattli, 4 Volumes. Edition 3, Beyrūt: mūasasat- al-risōlat,1988.

Aḥmad b. Fōris, al-Rāzi. Mujml al-lug̀ āt, ed, Zuhaīr Sulț̄̄n, 2 Volumes, Edition 3, Beyrūt mūasasat- alrisōlat,1986.

al-Samīn al-Ḥalabī, Aḥmad b. yūsif, al-Dur al-masvūn fi র́utūm al-kitāb al-maknūn, ed.Aḥmad muhammad al-Hुarāt,11 Volumes. dmshq: dar-al-qalam.

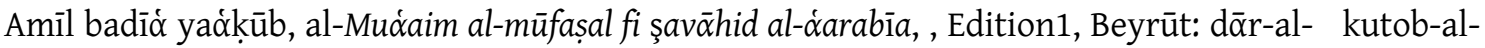
óilmìya,1996.

Alóaynī, Badr al-dīyn, Maḥmūd b. ahmad, al-makașid al-nahwīya fi şarih şavāhid al-alfia,

ed. Ali muhammad faḳir, Ahmad muhammad tavfik, 4 Volumes, Edition1, al-Ḳ̄hirat: dōr-alsalōm,2010.

Raḍi al-Dīn, al-Istrabōdi, şarih al-radīy li-kafiat Ibn al-ḥājib, ed. Yahyyō misrī, 2 Volumes, al-Riyōḍ: Jamiớt-Muhammad b. Sóvūd, 1996.

Sóeīd b. Masơda, abū al-ḥasan al'Ahfaş al-avsaț, móx̄inn al-ḳurōn, ed. hvdō ḳurōóhh, Volumes, 1 Edition, al-Kahirt: mktbt-al-Hुōnjīy,1990. 3

Seībavayh, 'Amrvū b. 'Asmān, al-Kitāb. ed, 'Abd al-Salam Mıhammad harvūn,4 Volumes, 3 Edition, al-Kahirt: mktbt-al-H̄ōnjīy,1988.

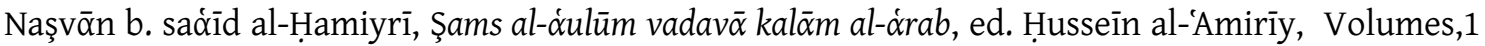
Edition, Dimaşk: dō̄r-al-fikr,1999. 11

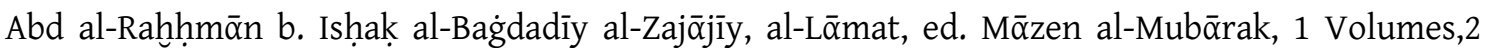
Edition, Dimaşk: d̄̄̄r-al-fikr,1985.

Abd al-Rahhhmōn b. ̄̄bī bakr al-Suyūṭī, şarih şavāhid al-muġnīy, ed. Ahmed zōfir, 2 Volumes, Lajnōtal-turōs-al-órabīy,1996.

Abd al-ḳ̄odir b. Omar al- Baġdadīy, şarih abyōt-muġnī al-labīb, ed.'Abd al-Aaziz rabōh -Ahmed yūsef, 8 Volumes, 2 Edition Beyrūt: dōr-al- Mōmvūn,1414. 
Ali b. Ismōóóil b. Sidah, al-mvhșaș, ed.Hualîl jafōl, 5 Volumes, 1 Edition, Beyrūt: dōr al-Turōs-alórabiy,1996.

Ali b. ómar al-Daraḳtnīy, Sunan al-Darakțnīy, ed. Şươeīb al-Arnaowț, 5 Volumes, 1 Edition, Beyrut: muassat-al-Resala, 2004.

Ali b. Muḥammad al-Uşmvūnī, Manhaj al-sālik il̄̄- alfiat Ibn Mōlik, 4 Volumes, 1 Edition Beyrūt: Dōral-Kutub-al-'ólmìyh, 1998.

Ali b. Muḥammad al-Haravīy, al-Auzhiaya fi x́ilm al-ḥurūf, ed. Abd al-Moóin al-Mallvūḥìy, 1Volumes, 2 Edition, Dimaşk: Majmớ al- Luġah -al- órabìya, 1993.

Muḥammad b. Mōlik, Şarah al-Kafía al-şā̄ia, ed. Abd al-Mvnóim Huaridīy, 5Volumes, 1 Edition, Makkah: Umm al-Kura mrkiz albahth al-ólmi-wa'iihya al-turas, 1982.

-Şraḥ tashil al-favayīd, ed. Abd al-Raḥmōn al-Sayīd, Muhammad badawī. 5 Volumes, 1 Edition, Misr: Hajr -ll-țibāet- val-naşir,1990.

Al-Alfiah, Ed. sulaymōn al-óyvūnīy, 1 Volumes, al-Riō ḍ: dōr-al-Minhō̄j,1428H. -

Muḥammad b. Ismớil al-Buḳarīy, sahih al-Bukarīy, ed. Muhammad Zahir al-Nōsir, 9 Volumes, 1 Edition, Beyrūt: Dōr-țvūḳ-al-Najōt, 1422H.

Muhammad b. Makram b. Manzvūr, Lisān al-Arab, 15 Volumes, 1 Edition, Beyrūt:

Dōr-Sōder, $1414 \mathrm{H}$.

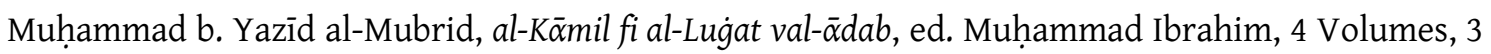
Edition, al-Ḳahira: Dōr-al-Fikr-al-Arabi, 1997.

Muhammad b. Yūsuf b. Ahmed muhib al-dīyn al-Ḥalabīy, Nazir al-Jayș, Tamhīd al-ḳavāid bișarh Tashil al-Favayid, ed. Ali muhammad, 11Volumes, 1 Edition, al-Ḳahirah: d̄̄̄r-al-Salōm,1428h.

Muslim b. al-Ḥajjōj Abu al-Ḥasan, șaḥiḥ Muslim, ed. Muḥammad Fuad Abdul-Baqi, 5 Volumes,1 Edition, Beyrūt: Dōr-Ihyȳ-al-Turas.

Yaḥyā b. Ziyōd b. 'Abdullōh al-Farrō, Maơnī al-Kuran, ed. Aḥmed Yūssif al-Najōti, Muhammad Ali al-Najjōr, 'Abdel-Fattah Ismóill, 3Volumes,1 Edition, Msr: dōr-al-Masrīy-lil'Tōlif valTarjamh.

Yaīș b. Ali b. yaīș, Șarḥ al-Mufașal, ed. Amil yớḳūb, 6Volumes,1 Edition, Beyrūt: dōr-al-Kutub alólmìyah, 2001. 


\title{
İbn Mâlik'e Göre Harf-i Cerlerde Tekârud/ödünç Alşsverişi
}

\author{
Turkiy ALALİ, Prof. Dr. Dursun HAZER
}

\section{Özet}

Arap dilinde araştırmacıların ve eleştirmenlerin hala araştırmakta olduğu bir çok olgu söz konusudur. Bu olgulardan bir tanesi; Tekaruttur. Tekarut ise manadaki lafız alış verişi olarak tanımlanabilir. Yani konuşmacının konuşma esnasında ihtiyaç duyduğu sebeplerden dolayı bir lafzın kendi manasını diğer bir lafza vermesidir. Bu olguyu harfi cerlerin birbiri arasında ve bazı zarf öbeklerinde sıkça görmek mümkündür. Nahiv alimleri bunu bir harfin diğer bir harfin yerine geçmesi olarak tanımlar. Nahiv alimleri bu konuda ihtilaf etmişlerdir. Şöyle ki onlardan bazıları bu durumu uygun bulup, caizdir demişlerdir. Diğer bir kısmı ise bu konuda katı tutum sergileyip, caiz değil demişlerdir.

Bu konu da temel olarak üç görüş vardır:

1. Görüş Basra ekolü görüşüdür. Bu görüşe göre harfler arasında tekarut yapmak doğru değildir. Onlar bu durumu tevil etmişlerdir. Buna da şaz deyip ayrıca zikredilir ancak kaide olarak alınmaz diye de ilave etmişlerdir.

2. Görüş ise bunu caiz görüp kullanılabileceğini söylemiştir. Buna delil olarakta şiir ve nesirde kullanılan örnekleri ileri sürmüşlerdir.

3. Görüş ise bir sebep olması durumunda bunun doğal olduğunu ve caiz olabileceğini söylemiştir. İbn Cinni'nin söz konusu sözleri bu durumu açıkça ortaya koyuyor. Müteahhirin alimler bu görüşler arasında genel olarak ikinci yani Kufe ekolünü tercih etmişlerdir. Bu nahivcilerin başında Muhammet b. Malik el-Endelusi gelir. Zira o bir çok eserinde Kufe ekolünün görüşünü teyit etmiştir. El-Endelusi, görüşlerinin tamamında Arap şiiri ve nesrinden kaynak göstermiştir.

$\mathrm{Bu}$ çalışmamızda İbn Malik harfin diğer bir harfin yerine geçmesi konusundaki bir çok görüşe yer verdik. Özet olarak Tekarut söz konusu olan başlıca harfler "ilâ, lâm, ba, fî, alâ, min" harflerdir. İlâ harf-i cerrin asıl kullanımı bir şeyin ve maksadın son bulması ve hasıl olması noktasındadır. Ancak Lâm harf-i cerrinden sahiplilik manasını alabiliyor. Fî harfi cerrinden ise zarf özelliğini alır. Bazen de bir şeyin başlangıcını ifade eden Min anlamında da gelir. İkinci harf Lâm harfi cerridir. Sahiplilik anlamı vardır. Bununla beraber bir şeyin başlangıcını ifade eden Min ve zarf özelliğine sahip olan Fî manasında da kullanılır. Söz konusu bütün bu harfler en çok tekarut yapılan harflerdir. Bunun yanı sıra Kâf harfi gibi az kullanılan ve yücelik manasınıda tekarut eden harfler de vardır. Bunun yanı sıra bazı cer harfleri isim manalarını alır ve cümleye bu isimlerin manasını verir. Arapların dil kullanımında "îlâ" "Bâ" "Fî" "Alâ" harfi cerleri beraberlik anlamını taşır. Aynı şekilde "Lâm" harf-i cerri; yanında ve sonrasında anlamını, "An" harfi cerri; sonrasında anlamını taşıdığını İbn Malik semâî delillerle ispat etmiştir. Böylelikle İbn Malik'in ekolü Kufe ekolüne mutabık olduğunu ve onların görüşlerinin sema yoluyla desteklediğini anlıyoruz. Burada kullanmış olduğu metod Kur'an-i delillere, Arap dilinde var olan şiir ve nesir örneklerine dayanır. 
Ayrıca nahivcilerin sözleri bu metod ve ekolünü desteklemektedir. Genellikle İbn Malik' in ekolünde Takarut zıt olur; yani diğer bir harfin manasını alırken kendi manasını ona verir. Aynı şekilde harf-i cerler zarfların anlamlarını alıp, cümlede o şekilde kullanılabilir. İbn Malik'in ekolüne göre sadece asli harf-i cerler bu bağlamda kullanılabilir. "Hâşâ, Hâla, Adâ" gibi bazen harfi cer görevi yapan, bazen yapmayanlar bu bağlamda değerlendirilmez.

Arap dilinde Takarut olgusunun varlığını teyit eden ve buna cevaz verenlerin çokluğundan, ayrıca bu kişilerin saygınlığından ve getirmiş oldukları delillerden dolayı açık bir şekilde Arap dilinde var olduğu anlaşılmaktadır. Elbette bu durum Arapçaya genişlik ve engellik, konuşmacıya özellikle zaruret durumunda esneklik imkanı sağlıyor.

İbni Malik'in Takarut (lafız alış verişi) konusunda zikrettğimiz görüşe sahip olduğu ve İbn Malik'in semâ yoluyla bunu genişlettiği, bu nedenle bir harfin başka bir harfin yerine geçtiğini ancak şiir ve düz yazı olan semâ yolu ile olduğunu söylemektedir. Aynı şekilde farklı ekoller olmasına rağmen önceki nahivcilerin görüşlerini almıştır. Böylece Basra ekolünden olan Ebu'lHasan el-Ahfeş, Kûfe ekolünden olan el-Ferrâ'dan nakil yapmaktadır. Bir harf başka bir harf yerine geçmesi konusuna karşı çıkan kişiye, kanıtı ve delili olduğu takdirde itiraz etmemiştir. Bunu inkar edenlerin argümanlarını tartışır ve onlara saygıyla karşılık verir. İbn Hişam, El-Muradi, Ebu Hayyan ve bunlar dışında birçok müteahhirîn alimler bu görüşü benimsediklerini söylemiştir.

Anahtar Kelimeler: Arap Dili ve Belagatı, Tekârud/ödünç alıp verme, niyâbe/yerine geçme, harf-i cerler, zarflar, İbn Mâlik. 


\title{
The Phenomenon of Grammatical “Borrowing "between Prepositions by Ibn Malik
}

\author{
Turkiy ALALİ, Prof. Dr. Dursun HAZER
}

\section{Extended Summary}

There are many phenomena in Arabic that scholars are still studying and vary between imitator, diligent, critic or successor of the past. These include the borrowing of the meaning of its utterances, that is to say, gives meaning to another for reasons that the speaker needs while speaking, such as necessity, rhyme in poetry, and the improvement and beautification of speech in assonance. This phenomenon is common in the prepositions and is either between the prepositions or between them and some adverbs. Grammarians say that happens when a letter works on behalf of another letter in terms of meaning.

The grammarians disagreed widely about this phenomenon where some of them said it is allowed and tolerate it while others prohibited it and were so rigid in that. This dispute resulted in two parties, the first party was the grammarians of Basra city who see that "borrowing or alternation between prepositions " and they interpret what seemed to be contrary for them appear in a way accepted in terms of pronunciation or judged it to be abnormal and can't be used as metrics. On the other party are the Kufa grammarians and some grammarians from Basra who see that "borrowing or alternation between prepositions "and their argument for hearing poetry and prose which is too much to be interpreted or to be judged as abnormal. Between these two opinions, and opinion arose in the middle which says that borrowing or alternation between prepositions is allowed, provided that there is a justification for it, which is the saying of ibn Jani.

The latecomers followed these opinions with the tendency by most of them to approve the Kufis opinion. Perhaps the most prominent grammarian among those was Muhammad ibn Malik Al Andalusi who approved the opinion of the Kufis and stated about that in more than one place, from his "Alafia of Bin Malik "which is his smallest grammarian book to his great books, such as the shrh tshi, shrh Al-Kfyaa and others supporting his discussion by depending on hearing from Arabs speech including poetry and prose.

In this research, he mentioned the most prominent statements and opinions of Ibn Malik, which he chose in the chapter on the alternation of one letter instead of the other. It can be said briefly that the most alternating letters in meaning are "ela, lam, ba'a, fee, ala" and "men "

Ela" is originally used to express the end the purpose, but it takes from the letter "lam" the meaning of the possession and borrows from "fee "The second letter is "lam" and its original meaning the possession and comes in the sense of adverb as "fee" and in the sense of superiority such as "ala" and the letter "lam" may also come to express the start of purpose such as "men" and to end the purpose like "ela" and the third letter is "baa" which is used to express collage in its original meaning but it comes out to other meanings taken from other letters such as the meaning of adverb borrowed from "fee" and it may be used to express superiority such as "ala ". 
The fourth letter is "ala" which was originally developed to indicate moral or material superiority, but it departs from this meaning and takes the meaning of others in speech, so it takes the meaning of exceedingly as "aan" and from "fee "the meaning of the adverb. It may come to the beginning of the purpose such as "fee" and the fifth letter is "men" which was originally developed for the beginning of the purpose, whether it is a place or time purpose, but it may come with another meanings such as justification and explanation like "lam" and superiority such as "ala" and also come to express exceeding such as "An" and come to express the meaning of adverb such as "fee" and these six letters are the most alternative among prepositions.There are fewer letters such as the" kaf" that comes in the sense of superiority such as "ala".

The prepositions may borrow meaning from some names and give its meaning in speech. The letter "ela" is in the speech of the Arabs in the sense of the meaning of the "maa" as well as "baa", "fee" and "ala" come to the companionship and the accompanying meaning. It also comes with the meaning of "maa" and "Lam "may come with the meaning of "enda" and "ba'adad" as well as "aan" which may come in the meaning of " ba'ada " and all this proved by Ibn Malik with audio evidence.

Thus, ibn Malik's approach has agreed with the Kufis clearly and supported his views by audio evidence His approach to proving this phenomenon is to take examples from Qur'an, and then to the Words of the Arabs of prose and poetry. He reinforces his views with the words of the greatest of Arab grammarians, regardless of their doctrines. Alternation is often contradictory according to Ibn Malik as a letter takes the meaning of a letter and gives it its meaning. Prepositions may also borrow meanings from certain adverbs, to give their meaning in speech. Alternation according to Ibn Malik is for letters, which are original prepositions, and not for other prepositions, which sometimes work as prepositions and sometimes not such as hasha, Khala, Waada and others.

Because of the many who say that there is a possibility of the presence of alternation in the speech of the Arabs and the majority of those who approved it with many shreds of evidence of this, it is clear that it is a common phenomenon in the speech of the Arabs, and it makes Arabic earns capacity, and gives the speaker flexibility, especially in the places of necessity.

Keywords: Arabic Language and Rhetoric, Contradiction, Prepositions, Prosecution, Adverbs, Ibn Malik. 
Alali-Hazer, The Phenomenon of Grammatical "Borrowing "between Prepositions by Ibn Malik 